University of Louisville

ThinkIR: The University of Louisville's Institutional Repository

Electronic Theses and Dissertations

4-1944

\title{
A follow-up study of thirty eight single unmarried mothers.
}

Rose Migdal

University of Louisville

Follow this and additional works at: https://ir.library.louisville.edu/etd

Part of the Social Welfare Commons

\section{Recommended Citation}

Migdal, Rose, "A follow-up study of thirty eight single unmarried mothers." (1944). Electronic Theses and Dissertations. Paper 2009.

https://doi.org/10.18297/etd/2009

This Master's Thesis is brought to you for free and open access by ThinkIR: The University of Louisville's Institutional Repository. It has been accepted for inclusion in Electronic Theses and Dissertations by an authorized administrator of ThinkIR: The University of Louisville's Institutional Repository. This title appears here courtesy of the author, who has retained all other copyrights. For more information, please contact thinkir@louisville.edu. 


\title{
UNIVERSITY OF LOUISVIIIE
}

\section{A FOIION-UP STUDY OF THIRTY EIGHT \\ SINGIE UNUARRIED MOT FERS}

\author{
A Dissertation \\ Submitted to the Faculty \\ of the Graduate Division of Social Administration \\ In Partial Fulfillment of the \\ Requirements for the Degree \\ of Master of Science in Social Administration
}

Graduete Division of Social Administration

By

Rose Migdal

Year

1944 


\section{UNIVERSITY}

LIBRARIES

This PDF document is a scanned copy of a paper manuscript housed in the University of Louisville (UofL) Libraries. The quality of this reproduction is greatly dependent upon the condition of the original paper copy. Indistinct print and poor quality illustrations are a direct reflection of the quality of materials that are available for scanning. The UofL Libraries greatly appreciates any better copies that can be made available for replacement scans. 
INAME OF STUDENT: Rose Higdal

TITLE OF IHESES: A Follow-Up Study of Thirty Eight Single Unmarried Mothers

APPROVED BY READING COMAITTEE COMPOSED OF THE FOLIOWING NEW BERS:

John J. Cronin

Annie Louise Pruitt

Robert I Kutak

NANE OF DIRECTOR: JOhn J. Cronin

DATE: 4/24/44 


\section{ACKNY WLEDGEAENTS}

The author gratefully acknowledges the assistance of the following:

Mr. John J. Cronin

Dr. Robert Kutak

Miss Geralōine B. Graham

Wir. $\mathrm{H} \cdot$ B. Baker

i) 


\section{TABIE OF CONIENTS}

Page

IIST OF TABIES

INTRODUCTIONT i

CIEAPTER

I. SCOPE AIN METHOD OF STUDY 1

II. SOCIAI HISTORY 7

III. HISTORY OF CONTACT WITH AGENCY

Summary of Findings Up to Time of Closing 38

IV. FINDINGS OF IIE FOIION-UP STUDY 42

V. CONCLUSIONS 82

APPEIDIX $\quad 87$

$\begin{array}{ll}\text { BIBLIOGRAPHY } & 94\end{array}$ 


\section{IIST OF IABLIS}

TABIE

$\mathrm{Pag} \theta$

1. Iive Eirths, Illegitimate Births, and the

Percentage of Illegitimate Eirths to Iive Births in Kantucky and Jefferson County for the Years 1939 and 1942

2. Age at Pregnancy of Thirty Eight Single

Unmarried Nothers

3. Educational ittainment up to the Time of Pregnancy of the Thirty Eight Single Unmarried Nothers

4. Occupations at the Time They Were Known to The Children's Agency of Thirty Eight Single Unmarried liothers

5. Intellectual Capacity of the Thirty Eight

Single Unmarried Hothers

6. Organization of the Homes of Thirty Eight

Single Unmarried Nothers in Relation to the Age

of the Unmarried liother When It Became Broken

7. The Economic Status of Thirty Eight Single Unmarried lothers at the Time They Were Inown to Children's Asency. Louisville, Kentucky

8. Attitudes Toward Their Illegitimate Pregnancy of Thirty Eight Single Unmarried wothers

9. Attitudes Towarả Their Illegitimate Children

of Thirty Eight Sinele Unmarried Mothers

10. Attitudes of the Families roward the Unmarried liothers of the rhirty Eight Single Unmarried Mothers

11. Attitudes of the Families Toward the Illegitimate Children of the Thirty Eight Single Unmarried Mothers

12. Relationship Eetween the Attitudes of the

Families Toward the Unmarried Mothers and Toward Her Ille gitimate Child of the Thirty Eight Single 
13. Marital Status of the Fathers of the

Illegitimate Chilaren of the Thirty Eight Single

Unmarried liothers

14. Relationship Between the Unmarriea jother and the Father of Her Child of Thirty Eight Single Unmarried hothers

(Percentage Comparison with the Rome study)

15. Whereabouts at the Time of closing of the Thirty Eight Illegitimate Children in Relation to the Whereabouts of the Thirty Eight Single Unmarried Nothers

16. Marital Status of Thirty wight Single Unmarriea Nothers In Relation to mom the Unmarried Nother Married at the Time the Follow-Up Study Was Made

17. Marital Status of those Unmarried Mothers Who Had Narried the Fathers of Their Children and the Marital Status of Those Unmarried Nothers Who Fad Married lien Other Than the Fathers of Their Children at the Time of the Follow-Up Study According to Number and Percentage

18. Length of Time Elapsed Between the Birth of the Illeqitimate Chilo and Marriage of Those Twenty Eight Unmarried Mothers Found to Have Niarried at the Time of the Follow-Up study

19. Subsequent Children, Iegitimate or Illegitimate, Born to Thirty Eight Unmarried Mothers Up to the Time of the Follow-Up study

20. Whereabouts of Thirty Eight Illegitimate Children in Relation to the Whereabouts of Their Unmarried Hothers it the Time of Closing in ComParison With the Time of the Follow-Up

21. Economic Status at Time of the Closing and at the Time of the Follow-Up Study of Thirty Eight Single Unmarried Mothers

22. Occupations of the Thirty Eight Single

Unmarried Wothers at the Time of Closing and at the Time of the Follow-Up study

23. Social, Home, Emotional, and Vocational

Adjustment Ratings of the Twenty Seven Unmarried Motrers in Relation to Their Ceneral Adjustment Rating 
24. General Adjustment Rating of the Twenty Seven Unmarried Mothers

25. Adjustment of the iwenty Seven Unmarried Wothers at the Time of the Follow-Up study According to the Whereabouts of Their Children and the Retention of Custody

26. Adjustment of the Twenty Seven Unmarried Mothers at the Time of the Follow-Up Study According to the Attitudes of the Family

27. Adjustment of the Twenty Seven Unmarried Niothers at the Time of the Follow-Up Study According to Community Knowledge of the True Paternity of Their Illegitimate children

28. Adjustment of the Iwenty Seven Unmarried Iiothers At the Time of the Follaw-Up Study According to Their Marital Status

29. Adjustment of the Twenty Seven Unmarried lothers at the Time of the Follow-Up Study According to Marriage to the Fathers of Their Children or to other Men 


\section{INT RODUCT ION}

This study of thirty eight unmarried mothers known to the Children's igency of Louisville, Kentucky is an attempt to find out what happens to these girls after the agency has terminated its contact with them. The study is not concerned with the problem of unmarried motherhood as such, but rather with the individual Eirl who gives birth to a child out of wedlock. The study, further, is not concerned with causal factors, the why and wherefore but rather with those conditions which brought the girl to a social agency when she finds that either she cannot help herself or her family and friends cannot cope with the problem.

Who is this girl who has "deviated from the social norm?"

What is her background--what are her feelings toward herself, her expected child, and the father of the child?

What happens to her after the social agency closes its case--when the social worker has done all she thought she was able to do in the situation or all that the girl, the agency, or the community allowed her to do?

If we assume that social case work is primarily only a temporary kind of help, then the Eoal of social case work in this instance is to help set free the Eirl's own resources so that she can utilize these to help herself. In reviewing this girl's life over a definite period after the case was 
"closed", we might learn to some extent whether or not she has attained that goal--of being able to utilize her own resources, without professional aid, to build a well-adjusted Iife for herself. In short, our aim is to compare the Iives of this particular group of thirty eight girls to find what they were Iike while known to the social agenoy and what they were like after a definite period of time had elapsed. The main question is: Have these firls who came to the social a gency for help with this perticular problem made adequate social adjustments?

The writer was interested primarily in those girls who kept their children. For these girls, it seemed to the writer, had the harder task. They had to go back to society, their communities, their friends, the ir families, and face them with the living symbol of their trensgression. How did they manage? What explanations did they give? How did they carry on? What effeat did it have on their Iives?

The answers to these and many other questions were sought. It was attempted, wherever possible, to work out objective means of answering these questions. In some areas, the writer thinks, the attempt was successful; in others, the task was too difficult--the devices for objectively measuring of certain phenomena were crude or non-existent. Special difficulty was confronted in the matter of defining social adjustment. General definitions concerning social adjustment were plentiful, but concrete statements as to whet it actually means to the individual were hard to find. Several inventories of 
social adjustment were found, but these proved to be not specifically applicable to the problem at hand. The writer was compelled to devise a measure based on the work of others in this area. This measure could only be used for that group of girls which the writer interviewed personally at the time of the follow-up study (twenty seven out of the total of the thirty eight girls); therefore an attempt will be made to go into detailed analysis of the ajustment of these twenty seven girls. However, specifie aspects of adjustment will be taken up for the total thirty oight girls.

Several studies that have been made on the problem of the unmarried mother were canvassed with the idea of making a comparison between those findings and the local cases. Early studies that proved helpful were those made by Alberta Guibord and Ida R. Parker in 1922 on What Becomes of the Unmarried Mother and that conducted by Mable H. Mattingly in 1928 on the Unmarried Mother and Fer Child. More recently, several students of the Smith College of Social Work had done some interesting work in this field, viz: Harriet Smith, A Descriptive Study of Unmarried Mothers In Relation to the Plans They Make for Their Babies; Anne Cohn, A Survey of Services to Fifty Unmarriea Mothers By The Jewish Board of Guardians; Ruth Rome, A Study of So:ne Faotors Entering Into the Un'married Mother's Decision Regarding the Disposition of Her Child; and Jane Hosmer, A Method of Predicting the Probable Disposition of Their Chilaren by Unmarried Wothers. The following study falls naturally into two parts. The 
first includes background material on the girls for the followup study and the history during the agency's contact. The second part embraces the findings from the follow-up study. 
SCOPE AND WETHOD OF STUDY 
CHAPTER I

METHCD AND SCOPE OF STUDY

The problem of the unmarried mother--the woman who brings a child into the world without legal attachment to the father-faces all nations which legalize marriage. The magnitude of the problem of illegitimacy in this country is indicated by the birth statistics compiled by the United States Census Bureau. According to the se reports, seventy thousand illegitimate babies--from three to four per cent of the total live births--are born in this country every year. Table one presents such statistics for the State of Kentucky, and Jefferson County, the area with which this study is concerned primarily.

\section{Table 1}

Iive Births, Illegitimate Births, and the Percentage of Illegitimate Births to Iive Births in Kentucky and Jefferson County for the Years $1939^{\mathrm{a}}$ and $1942^{\mathrm{b}}$

Iive Births Illegitimate Births Percentage Year Ky. Jeff. Co. Ky. Jeff. Co. Ky. Jeff. Co. $\begin{array}{lllllll}1939 & 60,982 & 6,129 & 1,195 & 227 & 3.1 & 3.7\end{array}$ $\begin{array}{lllllll}1942 & 66,105 & 9,481 & 2,190 & 237 & 3.3 & 2.5\end{array}$ a--Compiled from the Bullet in of the Department of Health, Vital Statistics Report; Public Health Department of the Commonwealth of Kentucky, July, 1940, Vol. 12 b--Ibid., Vol. 16, fugust, 1943

As we see from these data, Kentucky and Jefferson County fall 
somewhat within the national average of three to four per cent for illegitimate births. Illegitimacy is a recognized community problem and there are social agencies set up to deal with it. The above material is presented to give the reader a brief resume of the extent of the problem nationally as well as 10cally. But this study, as already mentioned, is concerned not with the total problem, but rather with the Individual unmarried mother and how she adjusted herself to unmarried motherhood after the social agency ceased to help.

The first step was to choose a number of cases of unmarried mothers known to the Children's Ágency of Louisville, Kentucky. There were aspects of a twofold problem involved in this step: First, sufficient time had to elapse between the closing of the case and the follow-up study to allow for social adjustment, and secondly, too lone a lapse between the closing of the case and the follow-up study would have meant diminishing returns in terms of finding the gir Is.

The date first chosen was to allow a lapse of three to. four years between the closing of the case and the follow-up study made in Noveraber and December 1943. This would have necessitated using cases that were closed in 1940. But because of the controls applied, the number of suitable cases closed in 1940 proved insufficient, and it became necessary to go back to 1939 and the latter half of 1938. As a result, the lapse of time between the case closing and the follow-up study was extended from three jears to five and one-half years.

The controls governing selection of these cases were as 
follows:

1. Only white unmarried mothers were chosen.

2. As it was pointed out in the introduction, only those girls were chosen who kept the custody of their children. "Kept the custody of their children" was used in the broader sense. It included the girl, who, although at the time of the closing of her case still retained legal custody of her child, had voiced desire to yield it for adoption. In this broader sense, the term also included the girl who had placed her child in an institution not connected with the Children's Agency, presumably for the purpose of giving it up for adoption, but who at the time of closing of the case had not signed any legal release. It was not known by the agency at that time whether or not such expressed desire was carried out.

3. The girl had to be single at the time the child was conceived.

4. The last known residence of the girl had to be the city of Louisville or surrounding area, so that the girl might be located readily for the follow-up study.

5. The case had to be closed between July 1, 1938 and December 31, 1940.

6. Both girl and child had to be alive at time of closing.

Forty eight cases in all were found which met all of

1. It was felt by the writer that the attitude of the Negro community in this geographical area towards this particular problem is on the whole somewhat different from the attitude taken by the White community. However, deviations in both groups are recognized. 
these conditions.

Three schedules were draw up, one covering the girl's social history, another the period of contact with the Children's Agency, and the third the follow-up interview and study. The first two schedules were filled out through analysis of the case recora. The third was derived from follow-up interviews with the girl, her mother, or with others acquainted with her present life, and through records of other social agencies which had contact with the girl or her family since her case was closed by the Children's Agency.

Many limitations presented themselves which more or less had to be accepted. First of these was the inconsistency of Information among case records. Since the records were not compiled with, the idea of research in mind, but as the routine function of the case worker, some lacked data pertinent to this research. Since the records were selected without concern as to how much work had been done with the various girls by the agency worker, they varied in completeness, some being records of intensive work with an individual, others not so intensive, and still other cases lacking information applicable to the present study. It must be mentioned that the Iimitations do not necessarily reflect upon either the agency or the worker, but nostly are aue to the fact that in those cases where there was least information, the Eirls involved chose to sever contact with the agency at an early stage. The reasons for this severance are outside the scope of this

$\overline{2 \cdot S e e}$ appendices $\dot{H}, B, C$ 
study

Secondly, there were linitations in the follow-up work that was done. This follow-up included clearing through the Social Service ixchange of Louisville and served a twofold purpose: it often provided clues to the present whereabouts of the girl or her family, and revealed what other social agencies, if any, had contact with the girl and or her family subsequent to the Children's Agency's activities. As a result, numerous records from other social agencies were read. An attempt then was made to locate and interview the girl, some member of her immediate family, or a friend well acquainted with her past and present situations.

Thirdly, sufficient information was obtainable concerning only thirty eight of the forty eight girls originally selected for this study. The sources of the follow-up information on these girls were as follows:

Twenty seven, the girls themselves

Six, mothers of the girls

Five, friends, relatives or social workers

Ten, not located or known to have left the city

Also recognized were the general limitations of inherent weaknesses in the case study method as a whole. As cottrell and Burgess point out in their work, Predicting Success or Failure in Marriage, the case work method is "the method of empathy, which means that the observer must partially identify himself with the subjects studied.... At the same time that the investigator is identifying himself with the subject, a part 
of his personality system must be reserved to observe and note what has been going on.... In conclusion the fact must be faced that the interpretation of case studies.... is not standardized and that its virtue and weakness inhere in the lack of standardization. There can be no guarantes that any two persons using this method on the same case will arrive at the same results."

3. E. W. Burgess and I. S. Cottrell, Predicting Success or Failure In Marriage (New York; Prentice-HaII 1939) p. 38 
SOCIAI HISTORY 
This chapter supplies a general picture of the group of girls under study. This sizing up is derived from the first schedule of the social history of each girl, referring to age, education, intellectual capacity, vocation and other related factors. It provides the necessary background for a comparison in the follow-up presentation between what was and what is.

In analyzing the ages of the girls in the present group, information first was obtained on the ages of unmarried mothers taken up in other studies, and these figures were compared with the figures obtained in this study. Guibord and Parker in their study found the average age at time of pregnancy of the girls they studied to be twenty one years, the youngest being fourteen and one half years and the oldest thirty five years. A stuay conaucted by Mabel Higeins Mattingly showed more than half of her group of fifty three cases fell between the ages of nineteen and twenty one. In a more recent study, made by Ruth Rome, of thirty cases of

4. A. Guibord and I. Parker, What Becomes of the Unmarried Mother, (Boston; Research Bureau of Social Work, 1922) p. I5 5. M. F. Mattingly, The Unmarried Mother and Her Child, (Cleveland, School of Applied Social Sciences Western Reserve University, 1928) p. 15 
unmarried mothers, it was found that forty three per cent of the group were younger than twenty at time of pregnancy.

Bel ow is a breakdown of the Children's Agency of

Louisville, Kentucky group according to age at pregnancy, these figures being presented for comparison with information obtained on other groups.

Table 2

Age at Pregnancy of Thirty Eight Single Unmarried Mothers Age at Pregnancy Total Unmarried Mothers 38

Less than 15 years

0

15 years less than 17 years

8

17 years less than 19 years

11

19 years less than 21 years

10

21 years less than 23 years

5

23 years and over

3

Unknown

1

a--in referring to the thirty eight single unmarried mothers in Tables 2 to 12 inclusive, the writer meant the thirty eight whose cases were closed between July 1, 1938 and Dec. 31, 1940

The average of the group studied herein is found to be around nineteen years, the youngest being fifteen and the oldest thirty two. Of this group, seventy nine per cent proved to be younger than twenty one.

A comparison shows the group here to be a good deal younger, on the whole, than the unmarried mothers considered in other studies. This might be due to several reasons, the principal one being the selection for this study of only those

6. R. Rome, "A Method of Predicting the Probable Disposition of Their Children by Unmarried Hothers", Smith College Studies of Social Work, Vol. I; (1940) p. 172 
girls who became pregnant illegitimately when they were single; those who are or have been married having been eliminated. There also is the possibility that the different regions in which the several investigations referred to were made has some bearing. Quite a number of the girls studied here have a rural Kentucky or Tennessee family background. Concerning education, it was found, as detailed in Table 3, that eighteen per cent of the group whose educational attainment was known, and this took in all but five of the thirty eight, had less than an elementary school education or had not attained the eighth grade. The remainder had at least completed elementary school.

Table 3

Educational Attainment Up to the Time of Pregnancy of the Thirty Eight Single Unmarried ifothers

Grade Attained

Total

Less than 3pd grade

3 rd grade less than 7 th grade

7 th grade less than 9 th grade

9 th grade less than IIth grade

High School Graduates

Beyond High School

No Report
Unmarried Mothers 38

0

3

15

10

3

2

5

Knowledge of the educational attainment of this group gives a clue to the general occupations of the girls. only two Eirls in the group who had attended a business college had any definite formalized instruction as to a vocation, as 
far as could be determined. The three who were graduated from high sohool also might be considered as having had at least some formal preparation for earing a living. This makes a total of only five among the group of thirty three about whom educational information is avallable who had some preparation for earning a livelihood.

Se emingly substantiated by the findings concerning occupation is the writer's assumption that most of the girls sought to support themselves through domestic service and unskilled employment which did not require specialized skill or training.

\section{Table 4}

Occupations at the Time They Were known to the Children's Agency of Thirty Eight Single Unmarried Mothers

occupations

Total

Domestic Servant

Waitress

Factory Labor

National Youth Administration

Clerical

a

Not Working

Unknown
Unmarried Mothers. 38

14

8

4

2

1

7

2

a--the category of not working included three girls who were still in school and four girls who could be said had never worked

It will be interesting later to compare this with the occupations of the girls at the time of the follow-up, in view of the economic changes going on in the nation as a whole and 
their effect upon this community in particular. Just at the time these girls were coming to the agency--in 1939 and 1940-the nation was changing from a peacetime to a wartime economy. These changes brought with them tremendous economic opportunity. Later on, it is noted how many girls were able to profit from these new opportunities to better their economic status, their vocational status, or both.

Most of the case records contained no reference to any psychometric examinations, but many of them included feneral statements by the particular worker as to her impression of the girl's intellectual capacity. These might be used as a somewhat fair measure.

\section{Table 5}

Intellectual Capacity of The Thirty Eight Single Unmarried Nothers

Intellectual Capacity

Total

Average or above

Dull

Defective

Unrecorded
Unmarried Mothers

38

14

8

2

14

The writer's general impression is, although adequate objective measurements are lacking, and information for the group is incomplete that on the whole this group is quite well balanced as to intellectual capacity.

Here it is attempted to review, in so far as it is possible to determine from the individual case records, the make-up of the families from which these girls are derived and what elements they contained--pathological or normal. 
It is unfortunate that in these, as in most social case records studied, the tendency is to stress the pathological and adverse items, while omitting in most cases the normal and favorable ones.

Specifically considered here are the homes from which came this group of girls; their economic status; the social problems which either the siblings or the parents at one time or another presented.

In only fifteen of the thirty eight cases were the parents found living together. In other words, more than sixty per cent of the eirls came from broken homes, where either one or both parents were absent due to death or separation. But not even all those homes considered "unbroken" could be called "psychologically healthy". In fact, only four of the fifteen could be called healthy homes. This might seem a rather arbitrary division, since there exists no adequate definition of a good home to use as a basis for comparison with these homes. But the writer attempts to defend this attitude by listing some of the unhealthy elements found in the eleven homes described as psychologically unhealthy, in spite of the fact that the parents were living together.

1. This girl, since she had been a child, lived away from home with her aged maternal relatives, although her parents were together. In talks with her worker, the girl frequently expressed the thought that she was "rejected" by her parents. When the relatives no longer could keep her, 
she did not return to her parents, but chose to Ilve alone. So far as this girl was concerned, her home was inadequate. 2. In two cases the fathers were known to be heavy drinkers.

In one of these cases, the father had threatened to kill the girl if she failed to obey him, and the girl remained in mortal fear of him. This girl's mother confided to the workor that the father was brutal, despotic and physically cruel.

The second of the fathers had frequent fits of melancholia and the mother was described as "mentally peculiar."

3. "Constant quareling" between the parents characterized one home and the Eirl was "sick of it all."

4. The father of one girl was a deaf mute and a very poor relationship existed between father and daughter.

5. One mother was known to be "high-tempered and mentally peculiar" and the daughter said she and her mother never got along.

6. Still another family contained thirteen children. The girl appearing in this study was the oldest child and her frequently expressed feeling was that she had been rejected while the other children always were favored.

7. One father had been sentenced to the State Penitentiafy for hoving sexual relations with his daughter--the girl figuring in this study--over a period of two years.

8. Another family contained ten children, some of them known to the Juvenile Court for their own delinquencies. These children were felt to be chronically neglected and unsupervised. 
9. One father was known definitely to be mentally unstable and the paternal side of the family had a long history of mental instability.

10. In still another case, both parents were away from home all day, and the young girl was known to be running around unsupervised.

It might be concluded, after reviewing the above evidence, that only four of the girls could be considered as having come from what might be called good homes. This might be compared with Miss Rome's findings, i.e., that half of her girls, from a group of thirty, came from unbroken homes, but that only four were from relatively healthy homes psychologically.

\section{Table 6}

Organization of the Fomes of Thirty Eight Single Unmarried liwothers in Relation to the ige of the Unmarried rother when It Became Broken.

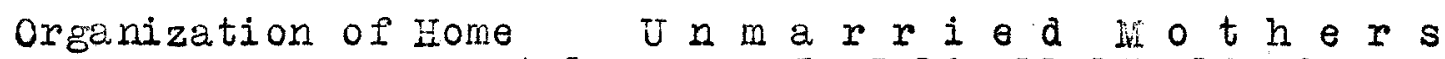
Total under 5 5-10 $11-15$ 16-20 unknown

\begin{tabular}{|lc|c|c|c|c|c|}
\hline Divorced & 1 & 0 & 1 & 0 & 0 & 0 \\
\hline Separated & 4 & 1 & 2 & 1 & 0 & 0 \\
\hline Finother dead & 13 & 3 & 6 & 1 & 2 & 1 \\
\hline Father dead & 7 & 3 & 2 & 1 & 1 & 0 \\
\hline $\begin{array}{l}\text { Parents living } \\
\text { toegther }\end{array}$ & 15 & 0 & 0 & 0 & 0 & 0 \\
\hline
\end{tabular}

Findings on the financial status of the families from

8. Ibid. p. 172 
which the thirty eight girls came are as follows:

\section{Table 7}

The Economic Status of Thirty Eight Single Unmarried Mothers at the Time They Were Known To Chilaren's Agency Louisville, Kentucky

Economic Status

Total

Totally or Partially Depenäent

Narginal Income

Fair

Well off
Unmarried Wothers

38

11

25

1

1

Compare this with Miss Rome's statement that "all but two (of her) families were found to be living under definite financial stress, either receiving relief from a public agency or strugeling independently on a sub-marginal income."

In exactly half of our thirty eight families, the records mention definite problems other than those of the illesitimate pregnancy of specific coneern here. These problems involved siblings, parents, or both Fourteen of these nineteen problem cases concerned illegitimacy or other sex irregularities on the part of one or more members of the respective families. Two of the girls themselves were conceived illegitimately, although in one case the mother married the father before birth of the child, the mother having so informed her daughter. Horals of six mothers of girls involved "were thought to be questionable." In seven cases, the girls' sisters were known, at one time or another, to have been pregnant illegitimately.

$\overline{9 . \quad I b i d ., ~ p . ~} 173$ 
Ten cases in this group had problems which involved more than one member of the family other than the girl of immediate concern.

It is difficult by statistical methods to provide a clear portrait of an individual's social backeround, so some illustrations are presented below. These illustrations come directIy from the individual records, although an attempt will be made to disguise any directly identifying material. only one of these records was chosen to illustrate what this writer meant by a good home background. The others were chosen on the basis of availability of material.

\section{ILIUSTRATICN A}

EDNA was born in 1915 in a rural section. She was the only child and led an unstable childhood. Her parents separated when she was quite young and she was brought by her mother to Louisville to live with maternal relatives. Her mother died while she was still a young girl and she was returned to her father, who had remarried and lived in a small town. Her father had other children, so most of the time she stayed with her paternal Erandmother. This grandmother died when she was seventeen and Edna returned to her maternal relatives in Louisville. Soon afterward the maternal grandmother with whom she lived died also. Edna then lived with a bachelor maternal uncle and kept house for him. Although her maternal relatives were interested in her, they did little to supervise or advise her. 
IIIUSTRAT ION B

IIIJINN lived with her family in three rooms on the first floor of a building which had been condemned as an unfit residence. The worker describes this building quite vivialy: "No other apartment in the building at this address was occupied and the building had a very dilapidated appearance.. The windows were broken and bricks were loose. The front steps were not attached to the door-stoop and the whole place was rickety looking. The inside of the home appeared to be just as bad.... the three rooms were in constant disorder, dirty and messy, and contained very dilapidated furnishings." The family consisted of the parents and eight children, Iillian being the oldest. Iillian's father was on a W.P.A. job and the family remained in the condemned house because, they claimed, they could live there free of rent. The case was referred to the agency by a probation officer of the Juvenile Court who had been interested in the family for some time. Fe requested that Iillian and her premeture illegitimate baby be accepted for plans. Iillian was seventeen at the time. The family had come to Louisville from the rural section of a Southern state when Iillian was nine. Several weeks after their arrival, a neighbor reportea, the father was in the City Hospital in critical conditionfollowing an accidental shooting. Hother and their five children were staying temporarily in two rooms. Since they had come, the father had lost 
his job and the family was destitute. A private relief agency gave financial relief for a little while. From then on there were recurrent reports that the family was destitute. When Iillian was fifteen the father deserted and the family was evicted. A neighbor who reported this to the relief agency had called a photographer from the local nowspaper to take pictures of the family with its belongings strewn in the street. The case record notes that Iillian seemed to be the only one objecting to the notoriety: "....she ran out to hide, but this man (the neighbor) brought her back and took a picture over her objections. The mother seemed very easy-going and said she never worried as someone had to take care of them." The Board of Education complained constantly that the children were truant, that the mother did not care for their clothing and ha a filthy house. The Juvenile Court learned that when Iillian was sixteen her mother was contributing to the delinquency of Iillian and other girls by taking them to cheap cafes and arranging dates for them with men. IIIUSTRATION C

IRENE was referred to the agency by her employer, in whose home she was living as a domestic. She had noticed that the seventeen year old girl was pregnant, discussed it with her, and requested maternity home care for her. Irene's parents had been farmers. The father drank heavily, but otherwise had been good to the girl. 
But her mother quarrelled continually with her father, and was considered by all in the community ras a rather difficult person." Mother finally took her belongings and deserted father. The farm was in her neme and she sold it. She took Irene to the home of the maternal grandmother. The father arifted from place to place, earning his way as a farmhand, and Irene hoard little from him. Her mother came to Louisville to seek work. For three years Irene was dependent upon the grandmother and maternal uncles who also lived there. She became devoted to them and attached to their home. She attended county school to the seventh grade (it was a rural homo). The girl rarely saw her mother or heard from her. Irene's mother appeared suddenly. She had married and wanted to take Irene to her new home with her. Irene was unhappy about leaving and fought against it. Her relatives also remonstrated with her mother in their fight to keep the girl. While in the relatives' home, Irene became attached to an uncle who was much older than she. As a young man he had worked on neighboring farms, but had become disabled and could not work. This uncle later became the father of Irene's illegitimate child. Irene, despite the protests, went to live with her mother, stepfather and his two children. She never returned to school, for her mother went to work immediately and Irene was required to take care of the two 
children, and do the cooking and the housework. The girl later said she was not allowed any privileges or pleasures. An aunt reported that Irene came frequently to her home in those days, crying over difficulties, Irene, unable to reconcile herself to the situation, at fifteen left home and found herself a domestic job.

\section{IIIUSTRAT ION D}

FLOREYCE'S mother came to the agency seeking advice concerning her sixteen year old daughter, who then was approximately seven months illegitimately pregnant. The worker reports the "mother made an excellent impression by the calm manner in which she faced the situation. The matter had been discussed by father and the older brothers and sisters and it had been decided they would do the best they could for Florence without having the situation ruin her for life. Florence and her child would be accepted in the home and the child would be reared as a member of the family." The rocord says the "mother spoke in affectionate terms of her children and showed pride in them. Her oldest son in in the army. The next oldest is an attorney. One girl is married, another is attending Business College. Florence has just finished Junior H.S. and intended to start High School; three younger girls are still in school. Father was an engineer at one of the prominent buildings in the city and earned an adequate income. The home is a modest cottage in a neighborhood of factory and industrial workers. The home is 
quite comfortably furnished and it is evident that all the members of the family are closely attached to one another. Members of the family came in and out during the interview, and al though the younger children did not seem to be interested in what the problem was, they seemed to know that there was some trouble without showing curiosity about it. It was apparent that the parents' first concern was to shelter Florence and consider her future. Father seemed to assume financial and other responsibilities toward the expectant child. Florence herself was a rather attractive Eirl. Although she was quiet and volunteered little in the discussion she seemed friendly and willing to cooperate with us. She also showed a certain gratitude and affection in her relationship with her parents."

Analysis of the family backerounds leads to the belief that most of the girls did not come from homes such as Florence's, where the relationship between the parents and the girl and the girl and her siblings were based on affection and sympathy. Most of the girls came from homes where relationships between parents and children were strained, or shattered through death, desertion and divorce. only two of the girls were from homes where there was little or no financial stress.

This does not mean to imply that most unmarried mothers come from such difficult environments. It is only for the particular group in this tady that the writer can araw 
conclusions. But it would be extremely interesting if a really unselected group of unmerried mothers were to be studied in regard to their family backgrounds. An "unselected group" would mean inclusion of those unmarried mothers who do not ask help of a social agency, and those who do not give birth to their illegitimate children in the city hospitals or in subsidized maternity homes.

It is the writer's belief that because the group studied comes from the files of a social agency, the individials' socio-economic status necessarily is lower than the average individual's status. One whose financial and community position is more secure can resort to private hospitals without divulging to a social worker her personal experiences. Also, if one's family group is well integrated, they can meet the emergency more readily without outside aid. This, is, of course, mostly conjecture, but it seems that such a study would be worthwhile if it were at all possible.

Relatively few records contained references as to whether the firl showed any problems as a child or at least prior to her illegitimate pregnancy. The difficulty in this respect again is traced back to the fact that many of the cases involved were closed before the worker had opportunity to procure sufficient data concerning the girl's history and social background. Below is presented all the material available regarding the thirty eight cases in this respect.

Eighteen of the girls presented definite problems to their parents or others caring for them preceaing the 
illegitimate pregnancy. Eight of the case records say definitely that the girls were normal children and presented no previous problems till their families were confronted suddenIy with the illegitimate pregnancy problem. In the remainder of the cases, no mention was made of this factor.

In ten of the cases, the problems contered about the fact that the girls started to run around until all hours of the night, while their families were unable to exercise control. It is to be noted that many of the girls in this category came from such environments as Edna and Irene, previousIy described, where parents were preoccupied with financial worries, where the girl felt implied or direct rejection, or where the father, generally the controlling member of the family, either was disinterested, incompetent because of arink or otherwise, or absent entirely.

Included amone this group of eighteen problem girls are two who from childhood had shown excess timidity in social relationships or who had expressed feelings of emotional deprivation. Possibly there were more girls in the group who might be included under this heading of excess timidity and emotional deprivation but who have been omitted from this category because that has not been expressed clearly in some of the records.

It is the tendency on the part of most people to look upon as problematic only those expressions of behavior thet bring forth annoyance, whereas the child who sits quietly, 
does not speak till spoken to and blushes whenever she does, and who never gets into scrapes, is regarded as the "model cinild." 
HISTORY OF CORTACT VITH AGEACY 


\section{CHAPTER III}

\section{HISTORY OF CONTACT WITH AGERCY}

All must agree that pregnancy itself is a tremendous emotional experience, even when the mother is joined legally to the father of her expected child. All the precautions, taboos, customs and folkways that have developed around approaching motherhood, pyramided upon the momentous physiological changes that occur within the woman during pregnancy, cannot but help to exert a profound influence on her attitues in many ways.

Now take this experience, which is fraught with emotional dynamite in even the most favorable of circumstances, and transfer it to a setting that does not conform with the generally accepted pattern of social behavior. What are the reactions obtained?

Take the girl who becomes pregnant without legal tie to the father, frequently even lacking an emotional tie with him, and how does she react? Most of these girls, it has been determined, have families or relatives with whom they live or with whom they maintain close social contact. These families and relatives also have been conditioned to the generally accepted pattern of society; how do they feel about the transgressing girl, the expected child and the situation into which 
the girl has thrust herself and perhaps them? These are some of the questions which this chapter takes up concerning the group which has been studied hero.

Also, what about the father of the child--what is his role? What was his relationship with the girl? Are we to assume that most of these girls were victims of the powerful will of the male for a sexual outlet? or are we to assume that the sexual relationship incurred was a natural outgrowth of the affection or love the girl and man had for each other? Or was it in many cases still another kind of relationship? These questions also are explored in this chapter.

Still a third group of questions is taken up here. What was the disposition of the case or what was the situation at the time the case was closed? Where was the eirl in relation to the whereabouts of the child? Was paternity established-the legal procedure--and was the father assuming any financial responsibility towards his child? What was the girl's marital status when the case was closed?

\section{A. Attitudes}

1. Of the girl towaras the situation.

It was attempted to follow the categories devised by Miss Anne Cohn in her master's thesis, Survey of Services Given to Unmarried Mothers by the Jewish Board of Guardians. Her oategories for measuring the reaction of her group of

10. Anne Cohn, "Survey of Services Given To Unmarried Irothers by the Jewi sh Board of Guardians", (Unpublished M.S. dissertation, Smith College, School of Social Work, 1938) p. 136 
girls to their illegitimate pregnancy were as follows:

a. Reaction of devastating shame and guilt with a few healthy compensating factors;

b. Iittle feeling expressed, due to repression, duflness, superficial emotional reaction, or inarticulateness;

c. Fairly mature facing of reality pressures on an adequate adult level.

is mentioned above, an attempt was made to measure our own thirty eight girls' reactions under these categories, but it was found that material embodied in the case records at hand did not lend itself to such interpretation. Instead, there were found such reactions as are reflected in these statements:

"Worker felt she had little conception of the responsibility involved."

"Mary seemed to be carefree and brazen about her condition and seemed to have no worries or responsibilities."

It therefore was thought necessary to devise our own set of categories applicable to the group at hand. Also there was the factor that only twenty seven of the thirty eight cases included references to reactions, so eleven cases were not included in this analysis.

$$
\text { Table } 8
$$

The Attitudes Toward Their Illegitimate Pregnancy of Thirty Eight Single Unmarried Mothers

Attitude of Unmarried Mother Total

Constructive

Iittle feeling expressed

Destructive

Unrecorded
Unmarried Hothers 38

6

7

14

11 
By "constructive reaction" is meant that a good deal of maturity and realism were shown by the girl in facing the situation. This first category included such statements by the case worker as "she seemed ashamed and disturbed over her pregnancy, but determined to face and make the best of it for herself and her expectant child."

Next is the reaction indicating such destructive elements as unrealistic attitudes in the situation, extreme dependency on family or worker, devastating feelings of guilt, sheme, bitterness or confusion. Examples from the records: "Irene denied until the last minute that she was pregnant and was so emotional in telling her story that Mirs. G. was uncertain of the truth." "Edna was very timid and extremely upset over her condition. She dreaded to make application to a maternity home because she was afraid that girls in her condition would be mistreated."

Then are listed those cases shar ing little feeling expressed, due either to repression or duliness.

Such attitudes or reactions were shown by the girls rather early in their contact with the agency. It would have been interesting to learn whether these attitudes changed any, and how they changed, as the girl's contact with agency and worker increased. But it proved impossible to draw any definite copclusions from the records because of lack of sufficient data concerning this development.

It might be remarked that it is not very surprising to get such a large number of Eirls who react to their illegitimate 
pregnancy with bitterness, shame or guilt. our dealings here are not with clear-visioned, strong-willed transgressors who deliberately elect such an experience for themselves, but with girls who for one reason or another lack the wisdom, foresight and self-direction to keep themselves out of it. Illegitimate pregnancy resulting from illicit sexual rolationship is unwanted and in most cases would not occur if these girls knew how to prevent it, short of abortion.

2. of the Girl Towards her child

\section{Table 9}

The Attitudes Toward Their Illegitimate Children of Thirty Eight Single Unmarried Nothers

Attitudes Towaràs Children

Total

Iove and acceptance

Hostility and rejection

Ambivalence and confusion

Unrecorded
Unmarried Nothers

38

16

1

18

3

In trying to arrive at some conclusions as to how the se girls felt toward their children, the following categories" were used:

a. Love and acceptance;

b. Fostility and rejection;

c. Confusion and ambivalence.

Thirty five of our cases reported some reference as to how the girl felt toward her child. Some sixteen of these (or approximately forty six per centl expressed feelings or acted in such 
a way as to confirm feelings of love and acceptance of their children. Eighteen (fifty one and one half per cent) showed feelings of confusion and ambivalence toward their children. In only one case did the worker report continued hostility and rejection of the child on the part of the girl. It is not surprising that only one showed such feeling, in view of the fact that our thirty eight cases included only those who retained custody of the child. It is interesting to compare our results with those of Miss Ruth Rome, "ll whose study also concerned only those unmarried mothers who retained custody of their child. She cited, among thirty cases, twenty five showing love and acceptance of the child, five showing confusion and ambivalence, and none showing hostility and rejection. On the other hand, there are Miss Cohn's results, wherein an unselected group of unmarried mothers were found to be divided as follows: thirty three per cent showing love and acceptance; twenty five per cent, hostility and rejection, and forty two per cent, confusion and ambivalence.

3. Of the Family Toward the Girl

How did the family of the Eirl feel towards her and her illegitimate child? Did they sympathize with her throughout or did they reject her and feel that she had brought "disgrace and shame on their house"? How did they feel toward her child--aid they accept it as a member of their own family, their own "flesh and blood", or tend to look upon it as a social or financial kurden?

11. R. Rome, Op. Cit., p. 177

12. A. Cohn, Op. Cit., p. 111 
Table 10

The Attitudes of the Families Toward the Unmarried Mother of the Thirty Eight Single Unmarried Nothers

Attitudes

Total

Sympathetic

Ambivalent

Rejecting

Ignorant of the Situation

No family

Unrecorded
Families

38

18

10

5

2

1

2

4. Of the Family Toward the Chila

Table 11

The Attitudes of the Families Toward the Illegitimate Children of the Thirty Eight Single Unmarried Mothers

Attitudes

Total

Love and Acceptance

Ambival ence

Rejecting

Ignorant of Paternity

No family

Nor recorded
Families

38

16

1

11

2

1

7

Were the feelings of the family towards the girl and child identical or did they differ? If they differed how did they differ? 
Table lz

The Relationship Between the Attitudes of the Families Toward the Unmarried Mothers and Toward Her Illegitimate Child of the Thirty Eight Single Unmarried Mothers

Toward Wother

Toward Child

Total Sympat. Ambiv. Rej. Unk.

\begin{tabular}{|lc|c|c|c|c|}
\hline Total & 38 & 16 & 1 & 11 & 10 \\
\hline Sympathetic & 18 & 12 & 0 & 4 & 2 \\
\hline Ambivalent & 10 & 3 & 1 & 5 & 1 \\
\hline Rejected & 5 & 1 & 0 & 2 & 2 \\
\hline Unknown & 5 & 0 & 0 & 0 & 5 \\
\hline
\end{tabular}

The data in Table twelve indicates there were:

Twelve cases where the family was sympathetic to both firl and child; three cases of family being ambivalent toward girl and sympathetic toward the chila;

one case where family rejected Eirl but was accepting child sympathetically;

one case where family showed ambivalent feelings toward both Eirl and child;

four cases of family sympathy toward girl but rejection of child;

five cases where family was ambivalent toward girl and rejecting child;

two cases where family rejected both girl and child.

B. The Man in the Situation

A much wider age range for the fathers than for the girls was found. The oldest of the men involved was forty five and the youngest seventeen years old. Most of the men 
for whom data on age could be found in the case record (twenty five of the total thirty eight), were several years older than the Eirl who was his sexual partner. In only three cases was there found any great discrepancy in age between that of the girls and that of the man: one case where the girl was fifteen years old and the man thirty four; the second case where the girl was twenty five and the man was forty five; and the third the girl was ighteen and the man thirty three.

\section{Table 13}

The Marital Status of the Fathers of the Illegitimate Children of the Thirty Eight Single Unmarried Mothers Marital Status Unmarried Fathers Total 38

Single 15

Divorced 1

Married 6

Separated 7

Unknown

From the data in table thirteen it was found that only sixteen of the twenty nine about whom information as to marital status was contained in the case record, were legally free from attachment to any other woman. Thirteen of the men were legally attached to another woman, either living with her or if living apart from her, not legally separated from her. The relationships of the girls and the men in our group, fitted into three groupings; groupings similar to those used by Niss Ruth Rome.

13. R. Rome, Op. Cit., p. 188 
1. rape or attack--the girl was an unwilling victim of a man she had become briefly acquainted with, or a stranger.

2. casual relationship--a relationship in which the man and the girl had a somewhat longer and closer acquaintanceship before the occurrence of the sexual episode in which the girl was an acquiescent if not an enthusiastic participant.

3. Iove or relationship of long standing--cases in which the girl professed a deep attachment to the man; cases where marriage had been discussed; cases in which the had "kept company" with the man for at least a period of months.

In four cases the eirl claimed that the relationship was one of force or attack. In eleven cases the relationship was casual and in twenty cases the relationship was one of love or long standing. Let it be pointed out that in at least two of the four cases where the girl claimed force or attack the worker had some doubt as to the truth of these claims, since the stories were vague, indefinite, and inconsistent. In one case the relationship could not be defined in these categories, because the girl claimed that her maternal uncle, a man some twenty years her senior, was the father of her child.

Ruth Rome, who used categories very similar to the ones the writer used to define the types of relationship between the eirl and the man, obtained the following results ${ }^{14}$ as compared with this writer's results.

14. Ibid., $\varrho .175$ 
Table 14

Relationship Between The Unmarried Hother and the Father of Her Child of Thirty Eight Single Unmarried Wothers

(Percentage Comparison with the Rome Study)

Relationship

Total

Force or attack

Casual relationship

Iove or long standing relationship
Percentage of Unmarried Mothers Rome Study Present studya

$$
100 \%
$$

$10 \%$

$27 \%$

$63 \%$
$100 \%$

$11 \%$

$30 \%$

$59 \%$

a--Percentage calculated on the basis of thirty seven cases; omitting the one case where relationship not defined acoording to above categories

Unlike the findings of Ruth Rome ${ }^{15}$ who stated that "In none of the thirty cases studied was there any indication in the case record of interest on the part of the father in the welfare or disposition of the child", this writer found that in at least ten of the cases the father took a more or less active part in helping the girl make plans for the child. This was done by either givine financial aid, by discussing plans with the worker, the girl, or both or by voluntary establishment of paternity. In about half of the cases studied the worker succeeded in establishing some contact with the father of the child. Six of these men definitely denied responsibility in the situation. Thirteen admitted intimacies with the girl involved; some of them definitely stating that they were the fathers of the child. Of the

15. Ibid., p. 174 
remainder with whom the agency worker had no contact eight were not identified and the others either refused to cooperate, could not be located or the girl or her family did not want him consulted.

\section{Situation at Time of Closing}

At the closing of the cases, as previously mentioned, all of the thirty eight girls had retained the legal custody of their children. Eowever, this did not mean that all of the girls and their chilaren were together. Twenty six children and their mothers were found to be living together; while twelve were living in separate homes. The data in table fifteen take this matter up more specifically.

Table 15

Whereabouts at the rime of Closing of the Thirty Eight Illegitima te Children in Relation to the Whereabouts of The Thirty Eight Unmarried Mothers

Whereabouts

Chilaren

Totals With Wother Without Mother

Total 38

26

12

Child with mother in own home 20

20

Child with relatives

7

with mother

4

wi thout mother

Child in foster home

3

with notres

2

without mother

8

Child in institution

with mother

0

wi thout mother 
At the respective times the cases were closed thirteen of the eirls were married; six of them married to the father of their child. The remainder, twenty five, were sincle at the time the agency closed its record. In only one of these cases can it be said that the agency worker took an active part in bringing about the marriage of the two people involved. In two of the six cases where the girl married the father of her child, the men involved seemed to offer marriage without any undue pressure from either the girl, the family, or the agency. In the other four cases, including the one in which the agen cy had a hand in bringing about the marriage, it was evident that more or less pressure was applied to bring about this marriage by the girl's family, in one case with the aid of the Juvenile court.

In only nine of the cases was legal paternity established for the child, including the six legitimitized through the marriage of the girl and the father of her child. Twenty nine of the chilaren's legal status remained the same as when they first'became known to the Chilaren's Agency. 
SUDDARY OF FINDINGS IN RESPECT TO TPEE THIRTY EIGHT SINGIE UNMARR IED WOTHERS UP TO THE TINE OF CLOSING OF THEIR CASES

The ages of the girls at time of pregnancy ranged all the way from fifteen the youngest to thirty two years the oldest. Seventy nine per cent (79\%) proved to be younger than twenty one years of age.

The educational attainment of the group, it was found, was quite limited. Eighteen per cent (18\%) of the group had less than an elementary school education. Only five out of the thirty three for whom information on education was found in the case records had graduated from High School; two out of these five girls had gone beyond High School and received business training.

Most of the girls supported themselves through domestic service and other unskilled employment. Twenty two of the thirty six girls for whom occupation was known were either domestice (fourteen) or waitresses (eight).

References to the mental capacity of the girls in the records were comparatively few. In twenty four of the thirty eight cases the writer found some reference to this question. In even fewer cases were there any references to psychometric tests. On the whole, the findings were based on general statements made by the social workers, in the 
records, as to the intellectual capacity of their clients. From the limited Iindings it seemed that the sroup was wellbalancea as to intellectual capacity.

Twenty three of the girls came from broken homes. However, only four out of the thirty eight girls, it was concluded, came from what might be called psychologically healthy homes.

lust of the families from which the girls came were financially harassed. In fact, only one family was found to be living on a fair income and one family could be considered well off. The remaining thirty six families were either totally or partially dependent or living on a marginal income.

In nineteen out of the thirty eight families definite problems, other than those of the specific illegitimate pregnancy discussed in this study, were mentioned in the records; problems involving siblings, the parents or both.

Eighteen of the girls presented definite problems to their parents or the ones caring for them, before this illegitimate pregnancy. Eight of the case records definitely mentioned that the girls presented no previous problems to their families. In the remaining twelve cases no answer to this question of adjustment of the Eirl previous to her illegitimate pregnancy could be found.

The attitudes of both the girl and her family in this situation were explored. Most of the girls (fourteen girls) for whom information was obtainable showed destructive reactions towards their illegitimate pregnanoy when confronted 
with the situation. Seven girls expressed littlo feeling and six girls faced the situation in what was defined as a fairly constructive way. Eighteen girls, it was found, showed ambivalence and confusion in regards to their feelings towards their illegitimate children; sixteen girls showed love and acceptance of their children throughout; only one showed hostility and rejection towards her chile throughout; for the remaining three girls no information on this question was obtainable from the records.

is for the eirls' families attitudes in regards to the situation, it wasfound, that in eighteen cases the families were sympathetio towards the girls; in ten cases the families were a mbivalent in their feelings towards the Eirls; in five cases the families rejected the girls; in the remaining cases the families either did not know the truth of the situation, the Eirl did not have a family or the family reactions were not recorded.

us for the fathers of these illeaitimate children it was found that; sixteen fathers were legally free to marry if they so desired; thirteen fathers were legally attached to other women; for the remaining fathers their marital status was inknown.

In twenty two of the thirty eight cases the relationship between the father of the child and the girl was a relationship of love or long standing; in leven cases the relationship between the two was casual; and in four cases the girl 
claimed some force had been exerted upon her on the part of the father of her illegitimate child to enter into sexual relations with him. In the remaining one case the relationship could not be identified according to the above mentioned categories since the father of the girl's child was her maternal uncle, a man in whose home she had lived since she was a child.

The agency social workers were successful in establishing some contact with the fathers of the children in at least half of the cases. In ten of the cases the fathers took a more or less active part in helping the girl with plans for their children. Eight of the fathers were definitely not iaentified.

At the time of the closing of the atency's records all the thirty eight girls had retained the custody of their children. Twenty six of the children were living together with their mothers while twelve chilaren were living in homes or institutions apart from their mothers. Thirteen of the unmarried mothers had married up to the time of closing; six of those had married the fathers of their children. The remaining twenty five girls were still single.

Iegal paternity for the child was established in only three cases up to the time of the closing of the case by Children's Agency. 
FINDINGS OF THE FOIIOW-UP STUDY 


\section{CEAPTER IV}

\section{FIVDINGS OF TIEE FOLIOW-UP STUDY}

The follow-up study, as already mentioned, consisted of clearing through the Social Service Exchange of Louisville. Then the records of the agencies that had contact with the Eirls and/or her family after Children's AEency's closing date were read. 16 Next; every effort was made to locate each girl in order to interview her. If this were impossible, as it proved to be in some cases because of inability to locate the girl, or because she had moved from the city, the next person the writer tried to find was the mother of the firl. If this were impossible efforts were made to inter view other sources who would know of the illegitimacy situation, and what the girl's life was like at the time the follow-up study was made.

The information obtained from the mothers of the Eirls as well as the other sources were used only to analyze the.

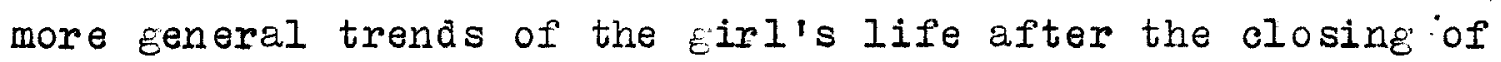
her record by the Children's Agency and also the factors that lent themselves more readily to quantitative analysis. Nore intensive qualitative analysis of the girl's life as it was at the time of the follow-up study and judgements as to

16. This included reopening's of the cases by Children's Agency 
whether her adjustment was good, fair or poor at the time, was made for the twenty seven girls with whom the writer has had direct contact through a personal interview that lasted on the average between an hour and hour and a half. Because of the increase in mobility in the community, aue a good deal to the war situation, a good many of the girls had moved from the community. It wis calculated that an average of about three visits were made before the girl, her mother or other sources that could supply information about the girl's Iife, could be located.

When the person we wished to interview was located, an attempt was made to explain to each the purpose of the visit. Stress was laid on the fact that they were asked to cooperate in a study that might help other Eirls who are or will be goine through the same experience--that of unmarried motherhood. Phey were assured that this study was confidential; that no information that would identify them would be included in the study. The implication was that they could now help with a problem thet they or the ones they were interested in had been helped with previously.

On the whole the writer was met with a genuinely friendy wish to cooperate with her and the agency. In only two cases did she meet up with some reluctance. In one case this was on the part of the girl who gave some information, but who when called on again, because the interview could not be completed the first time, explained that her husband had refused 
to allow her to discuss the situation any further. on the whole it was found that when the husband was present during the interview, the girl seemed to express herself less freely, although his presence was sometimes beneficial in that it helped the writer to observe for herself the relationship between the two. However, the girls, for the most part, took the attitude that it wes their own affair that was beine aiscussed, and desired to keep the husband out of it. The writer, naturally abided with the individual eirl's decision.

The second case where the writer met up with some opposition was on the part of one of the firls' mothers. She informed the writer that the girl had married, a man other than the father of her child, and was living in another city. This mother felt that the situation was part of the past and was to be forgotten. She did however, tell what had happened to the girl in general since she broke off contact with the Children's Agency, and pointed out that her opposition to discuss the matter did not stem from any ill feelings towards the agency, but that she felt that the family and the girl wished to forget as best as they could the whole affair and the $\mathrm{d}$ did not want any one to bring it up again. In this case it was suspected that there was a good deal of fear involved since neither the husband of the girl, nor a good part of the community knew the truth of the situation.

The social adjustment of the girl will be considered here, social adjustment necessarily implyine adjustment to 
a social environment. It was therefore, felt necessary to review briefly some of the changes that have ocourred in this environment since contact between the girl and the Children's Agency was terminated. These changes can be linked up directly or indirectly with the fact that the follow-up study was made in the months of November and December of 1943, a time when the world as well as the United States was at war.

No one will dispute the fact that a modern war brings with it tremendous social changes, changes that affect almost every indiviaual member of the community that is at war; changes the writer maintains will in some way affect the social adjustment of many of the girls here studied. Therefore, although no over-all attempt was made to draw any relationship between what has been and is occurring in the community to specific aspects of what is and has been happening to these girls, the necessity for outlining briefly some of these changes was felt.

Iouisville was considered during the time of the followup study as one of the major centers in the war effort. Through July, 1943, the Louisville Area received war supply contracts amounting to $\$ 580,000,000$. This was more than eighty percent greater than the value of products manufactured in the city during the year 1959.

17. Information on the situation of Louisville during the war era was obtained from hiehlights of reports and analyses published to Region if 5 of the War Manpower Commission. 
Employment in the Louisville area, both for male and female workers was at a record all time high during the period of the follow-up study. With the additional war plants in the area since $1940^{18}$ actual employment had more than doubled. Approximately thirty per cent of those who were in war work-total over 100,000 people--were women. Although there were, at the time the follow-up study was made, no over all statistics available, sample aralysis by the Iabor Market analysist of the War ianpower Commission for this area indicated that women working in industry and trades increased one hundred per cent during the war period in this area. With the induction of men into the arred forces on the one hand, and the expansion of industry on the other hand, women constituted the greatest potential supply of labor both nationally and $100211 y$.

The above brief picture of the economic and industrial expansion in this community indicates there was tremendous economic opportunity for all, and especially for women. This might have an effect in bringing about a change in the economic status and vocation of the individual unmarried mother at the time of the follow-up as compared to what it was at the time her record was closed by the Children's Agency.

In spite of the fact that up until the end of 1943, thirty thousand $(30,000)$ men had already been inducted into 18. The actual figures on how many new war plants were added in this area since 1940 was regarded as confidential material. 
the Armed Services from this community, there was by January 1 , 1944, an estimated eleven per cent increase in the population of the Louisville Area as compared with the population in the year 1940. This area had also a large Military Camp and Air Field nearby and as a result there was also a tremendous influx of soldiers into this area--young men who might offer opportunities for marriage or perhaps for further illicit sexual experience.

There are still other aspects of a war situation that max affect the total adjustment of the individual. The writer will not go into them here except to mention a few--the emotional and psychological effects of war on the individual; the breaking up of families; the separation from loved ones; the general picture of insecurity. All of the above and many other direct and subtle effects of war cannot help but affect the findings as to what happened to the group of thirty eight unmarried mothers.

FIID IIGS

A. A general Survey as to What Happened to the Thirty Eight Unmarried ifothers Whose Cases Were Closed By Children's Agency, Louisville, Ky., Between July 1, 1938 and December 31, 1940 at the Time of the Follow-Up Study In November and December of 1943

In the previous analysis as to how many girls had married at the time that the agency record for each was closed, it was found that thirteen out of the thirty eight unmarried mothers, whose children were conceived when they were single, 
had married. Six of these thirteen had married the fathers of their chilären.

What was the picture in relation to this question at the time the follow-up study was made? How many had married and to whom? How long after the child was born did they marry and what was their marital status at the time of the follow-up interview? How many were divorcea or separated from their husbands? How many of those who had married the father of their chilaren were still livine with this man?

How many had other children--legitimate or illegitimate-born to them after their case was closed by the agency?

How many girls' husbands, taking into consideration the war situation, were away from nome aue to induction into the United States Arred Forces? All these questions will be considered below.

Table 16

The inarital Status of Thirty Eight Single Unmarried Wothers In Relation to Whom the Tnmarried Hother Married at the time the Follow-Up Study was diade

Whom Narried

Total

Father of Child

Other Wan

Single
Unmarried nothers

38

8

20

10

At the time the follow-up was made it was found that fifteen more girls had married, making a total of twenty eight out of thirty eight who were or had been married at the time 
of the follow-up interview. Most of these girls--twenty girls-had married men other than the fathers of their children. The remainder--eight girls--two more than at the time of closing had married the fathers of their children.

A few of the girls who had married before or after the closing of their case by the agency social worker were divorced or separated from their husbands at the time of the follow-up study. It was interesting to compare the marital status of that eroup of firls that had married the father of their children and the marital status of that group that had married other men. It was however, felt that the number was too small to make any valid conclusions, although comparisons in terms of percentages of those married, divorced, or separated of the group that had married the father of their chilaren and those who had married other men will be made in table seventeen.

Table 17

Warital Status of those Unmarried liothers Who Had Married the Fathers of their Children and the Marital Status of those Unmarried Mothers Who Had Married wen other than the Fathers of Their Children at the rime of the Follow-Up study according to Number and Percentage

Narital status

Unmarried Itothers

\begin{tabular}{|c|c|c|c|c|c|c|}
\hline \multirow[t]{2}{*}{ Totals } & \multicolumn{3}{|c|}{$\begin{array}{c}\text { Number } \\
38\end{array}$} & \multicolumn{3}{|c|}{$\begin{array}{c}\text { Percent } \\
100\end{array}$} \\
\hline & Fas & O.M. & $S$ & Fas & $0 . \mathrm{M}$ & $S$ \\
\hline Hotal Married Fas & 8 & & & 21 & & \\
\hline $\begin{array}{l}\text { Divorced } \\
\text { Separated } \\
\text { Still Warried } \\
\text { Total Narried other wen }\end{array}$ & $\begin{array}{l}3 \\
1 \\
4\end{array}$ & 20 & & $\begin{array}{l}37 \\
13 \\
50\end{array}$ & 53 & \\
\hline $\begin{array}{c}\text { Divorced } \\
\text { Separated } \\
\text { Still Married } \\
\text { Total Single }\end{array}$ & & $\begin{array}{r}2 \\
2 \\
16\end{array}$ & 10 & & $\begin{array}{l}10 \\
10 \\
80\end{array}$ & 26 \\
\hline
\end{tabular}


As seen from the data of Table seventeen fifty percent of those who had married the father of their children were no longer living with them due to either divorce or separation as compared with only twenty per cent of those girls who were no longer living with the ir husbands who had married men other than the fathers of their children. As mentioned previously the numbers are much too small to draw any definite or valid conclusions. Nevertheless the results are significant, in the opinion of the writer.

Nine of the husbands were found to be out of the home because of induction into the Armed Services. Several other girls faced a future of having to separate from their husbands for the same reason.

\section{Table 18}

Length of Time Elapsed Between the Birth of the Illegitimate Child and Niarriage of those Twenty Eight Unmarried Irothers Found To Have iarried at the Time of the Follow-Up Study When itarried Unmarried Nothers Tota 1 Married 28 Before the child 1 yr. old

$4-5$

Unknown

The writer was interested in finding out at the time of the follow-up study how many girls had given birth to children 
other than the one the agency was interested in when it had contact with the girl. Specifically was she interested in finding how many girls gave birth to other illegitimate children after contact with the agency ended. Table nineteen gives information as to other children, legitimate or illeqitimate chilaren born to these sirls up to the time of the follow-up study in November and Lecember of 1943.

\section{Table 19}

Subsequent chilaren, Legitimate or Illegitimate, Born to Thirty Eight Unmarried wothers Up to the Iime of the Follow-Up Study

$\begin{array}{lcc} & \begin{array}{c}\text { Total } \\ \text { Unmarried liothers } \\ \text { Subsequent children }\end{array} \\ \text { He other children } & 20 & 20 \\ \text { legitinate only } & & 16 \\ \text { legitimate o illegit. } & 2 \\ \text { illezitimate only } & 2\end{array}$

Fad no other children

18

From the data in Table nineteen it was found that four Eirls again presented the problem of giving birth to a child out of wedlock. These four firls were all still single at the time of the conception and birth of the other illogitimate child. The births of these other illegitimate children occurred in a period of between two to four years after the birth of the illegitimate child that the writer was concerned with in this study.

No doubt if to these four repeaters were added the girl 
who indulgea in further illicit sexual relations, or the Eirl who conceived another child illegitimately, but who had rid herself of the child through abortion or miscarriage the number of so-called repeatess would be ereater. Unfortunately definite information as to the above question was found in only four other cases. One girl admitted to the writer that she became illegitimately pregnant again about three years after the birth of her first illegitimate child. The child was not born because of a self-induced abortion. The second girl admitted to the writer that she had been a prostitute for a year after she terminated her contact with the children's Agency. In the third case the mother of the firl told the writer that although the girl's present whereabouts were unknown to her, she felt certain that the eirl was prostituting. The fourth case included the girl who at the time of the follow-up study was married, but was known to be living with a man other than her husband although not formally separated from her legal spouse. This makes a total of eight out of the thirty eight girls known to have again transgressed or continued to transgress the cultural norm govering sexual activity.

In the preceeding chapter, it was found that twenty six out of the total thirty eight children were living together with their mother in either the girl's home, in a relative's home or in a foster home at the time the girl's recora was closed. The remaining twelve were at that time living away from their mother. All the thirty eight children were still 
the legal charges of their respective mothers. What was the situation as regards the whereabouts of the children in relation to the whereabouts of their mothers at the time of the follow-up study? How many of the girls had found it necessary or expedient to relinquish the legal custody of their children to others?

Table 20

The Whereabouts of Thirty icht Illesitimate Chilaren in Relation to the whereabouts of their Unmarried iothers At the Time of Closine in Comparison with the Time of the Follow-Up

$$
\text { Closing Follow-Up }
$$

Totals W.M. Wt.in. Totals W.M. Wt.i.

\begin{tabular}{|lc|c|c|c|c|c|}
\multicolumn{2}{r}{38} & 26 & 12 & 38 & 20 & 18 \\
\hline In own home & 20 & 20 & 0 & 20 & 20 & 0 \\
\hline In relatives home & 7 & 4 & 3 & 4 & 0 & 4 \\
\hline In foster home & 3 & 2 & 1 & 4 & 0 & 4 \\
\hline In institution & 8 & 0 & 8 & 0 & 0 & 0 \\
\hline Released custody & 0 & 0 & 0 & 10 & 0 & 10 \\
\hline
\end{tabular}

It was found that whereas at the time of closing the total number of children with their mother wes twenty six children, at the time of follow-up this number has been reduced to twenty children with their mother. Also, whereas all thirty eight of the girls had retained the legal custody of the ir children at the time of the closing of their recoras, ten of these had released the custooy of their children, presumably for adoption, at the time the follow-up study was made. 
Various reasons for giving up the custody of her child were given by either the Eirl or the informant.

Three girls claimed that they finally relinquished the custody of their children because of the interference of their families. Of these one girl bitterly regrettea her decision and felt resentful toward her family for what she termed foreing her to give her child up. The remaining two girls felt that al though it was hard for them to give their children up, nevertheless it was the best thing they could do for the children and for themselves under the circumstances they faced at the home. An informant told the writer of one girl who struggled with the idea of giving her child up for adoption for almost two years. When she finally decided to give her child up she said that the thing which finally caused her to make this decision was her observation of the married life of a girl friend of hers who also had had an illegitimate child before marriage. This girl friend had decided to keep her child. Our girl felt that her girl friend's husband constantly resented this illegitimate child and was at times suspicious and hostile towards his wife. Our girl decided that she too would some day want to get married, but she did not want the same thing that was happening to the girl friend and her child happen to her and her illegitimate child.

In one case the parents of the eirl adopted the child and were rearing him as their own. The firl was married and living away from her parents' home.

Four of the girls strugeled to keep their children without receiving any assistance from any of their families. This 
strugele proved too hard for them and they finally gave up. One girl of these four, when the writer interviewed her bitterIy regretted not having been able to hold out a little while longer without any assistance.

One girl claimed, and this claim was substantiated by recorads, that she had never signed any release of oustody of the child. A public child welfare agency in the community took the child from her. They claimed that the child was neglected in the home of the girl's mother where she was being cared for, and that the girl did not show much interest in the welfare of her child. When the writer interviewed this girl she still showed a good deal of bitterness and hostility towards this public child welfare agency, although about four years had passed since the child was taken from her. She also told the writer that she had by accident found out the whereabouts of her chilo, and she visited her regularly and threatened that she would some day institute proceedings for the return of her child.

As regards the legal status of these thirty eight children, in only three cases was legal paternity established. Six children were legitimized throukh the girl's marriage to the father of the child. Twenty nine children's legal status remained unchanged at the time the case was closed. At the follow-up study the situation as regards this question was almost the same except for one more case of legitimization through the marriage of the father and the mother of the child.

19. Although as previously noted eight girls married the fathers of their children, only seven were legitimitized through this because one girl married the father after she had given up custody of the child. 
None of the children were le gally adopted by their stepfathers. Although many of the step-fathers accepted their wife's illegitimate child into their home, assumed responsibility towards it and expressed feelings of affection and attachment towards this child, not one of the step-fathers had eiven the children the legal right to their names or assumed legal responsibility towards them. Many of the girls declared that the question had been discussed and that the husband had voiced a desire to adopt the child, but nothing had been done about it.

There are probably many reasons both conscious and unconscious for this reluctance on the part of the step-father to adopt his wife's illegitimate child. The writer believes that an important reason can be found in one of the statements made by one of the step-fathers that she had an opportunity to question on this point. He said that the "foing down and instituting proceedings for the adoption of Jimmie would mean raking up a part of the past we are trying desperately to forget. It would also mean that several more people would have to know about it (the illegitimate birth)." The writer wondered whether this was really all of it? She wondered if there was not an unconscious or perhaps even conscious element of hostility and jealousy towards his wife and her child contained in his reluctance to give the child legal recognition.

It should be noted here that when there was occasion to observe both the girl and her husband during the follow-up 
interview, the writer felt that the husband showed many more signs of shame and embarrassment over the situation than did the girl.

In comparine the economic status of these girls at the time they were known to the Children's Agency and at the time of the follow-up the writer ran into some difficulty. Two similar but not identical standaras were actually compared; at the time of contact with the agency the standards of the individual worker; at time of the follow-up study the standards of the writer. There was no objective measuring rod such as the comparative wage scales of the firl or person she was depending upon:

In the record the witer had to depend upon such factors as: remarks of the worker as regards the economic status of the Eirl or her family; descriptions of the nejghborhoods in which the girls lived; the descriptions of the physical appearance of the homes; and mention in the record whether the eirl or her family had recently been or were totally or partially depenoent upon a social agency for financial assistance. In the follow-up study observations of the neighborhood and home were made by the writer and wherever possible the financial situation of the girl at the time of the follow-up interview was discussed with either the EIr or the informant. On the basis of these aiscussions where the Eirl or the informant was encouraged to voice an opinion on what she judged the financial situation of the girl was 
at the time and upon the writer's own observations the data on table twenty onewere computed.

Because the decisions in wich of the four categories of economic status the indiviaual Eirl should be placed were admittealy subjective, the writer felt it necessary to define briefly what was meant by the categories of marginal and fair economic status. The other two catecories at the opposite ends are more or less self explanatory.

Warcinal--the girl or the family al though independent were constantly harassed by financial woes. Ixpressions such as "findine it difficult to make ends meet; just eekine out an existence; livine from hand to mouth", were used by either the Eirl or the informant to describe the economic situation.

Fair--The eirl was tetting alone quite well financially. The Eirl or the informant felt that the income was adequate not only to provide the bare necessities, but left some extra for little luxuries.

\section{Takle 21}

Economic status at Tine of the Closing and at the rime of the Follow-Up Stuay of thirty Eight Single Unmarried Mothers Economic Status Unmarried Hothers

Total Closing Follow-Up

58

38

Totally or partially dependent

11

3

Warginal

25

9

Fair

1

15

Well-off

1

0

3

Uncertain

$8^{a}$

a-- The writer felt the informant was too indefinite as to his assertions of the economic status of the sirl. 
Only three of the firls were considered to be financially dependent at the time of the follow-up study, in contrast to eleven of the girls considered to be pertially or totally dependent at the time they were known to the Children's Agency. only one of the girls of the three was financially dependent on a social agency for aid. Her husband had just been inducted into the United States Army, and the American Red Cross was helping out until she could receive her allotment, from her husband. The other two girls, considered aependent, were physically capable of earning their own livelihood, but one preferred to do nothing and live off the generosity of her family and the other was supported by a man with whom she was living, but to whom she was not married.

It can be concluded from the data on Table twenty one, if the findings are considered valid, that the economie status of the group was considerably higher at the time of the follow-up study than at the time they were known to the agency. Seven of the girls, although married to husbands who were employed or sending an allot ment, worked and thus helped to increase their income. 
Table 22

Occupations of the Thirty Eight Single Unmarried Mothers at the Time of Closing and at the rime of the Follow-Up Study

Vocations

Total

Domestic

Waitress

Factory

Clerical

National Youth Aäministration

Not Working

Telephone operator

Laundry

Practical nurse

Armed Services

Unknown
Unmarried Mothers $\mathrm{Cl}$ os ing:

38

14

8

4

1

2

7

0

0

0

0

2 Follow-Up 38 3 1 7 2 0 15

1

1

1 .

I

6

a--This included thirteen housewives, one girl who stayed at home and one girl who was supported by a man with whom she was living at the time.

Wider variation as to the occupations of these girls were found at the time of the follow-up as compared to the time the agency knew these girls. The writer attributes this phenomenon to the great increase in economic opportunity in the community, in many of the fields of economic endeavor. Greater opportunity apparently meant wider cholce in occupational pursuits. B. The Social Adjustment of the Twenty Seven Girls that the Writer Personally Interviewed. 
As mentioned at the beginning of this study the aim was to find out what had happened to the thirty eight unmarried mothers after a lapse of between three to five and a half years after these girls' cases were closed by the Children's Agenoy. Specifically did the writer want to judge what the social adjustment of these girls was after this lapse of time. An intensive study of the social adjustment of all the thirty eight firls was impossible because the technique that was devised for measuring this could not be appliea to all; it could be used only for those girls--twenty seven girls-whom the writer personally interviewed. The remaining eleven girls were included in analyzing the specific aspects of adjustment because although the information secured about their lives at the time the foliow-up was made was not complete enough to judge their total adjustment picture, the writer nevertheless considered some of the findings important.

In tryine to judge the social adjustment of these girls the writer was confronted with the problem of what is social adjustment. Were the girls socially well adjusted when they no longer presented specific problems to the community, or was the writer to take the more idealis tic view and say that they were socially well adjusted when they no longer showed either problems to society or to themselves.

Whatever can be said of the factors that caused their illegitimate pregnancy, whether it sprung from neurotic motives, environmental or biological causes, or whether it was caused by a combination of these, the situation that 
resulted was not one that conformed with the accepted norms in the society in which these girls lived. It was not a normal reaction to tensions created and for that reason al one, excluding all others that might have existed they might be 20

juaged to have been maladjusted. But are these girls adjusted now simply because they no longer present such or similar outward signs of maladjustment?

The writer did not feel that it would be enough just to summarize what the girl's life was at the time of the followup study and let it so at that. A more concrete, a more objective measure, a measure that would lend itself more readily to statistical analysis than that of mere illustration, was àsired.

The problem was approached in two ways. The first thing the writer did was to read a good deal of material in this controversial area of social adjustment--from the sociological, psychological, and social work point of view. The writer tried to form from these readings a general idea of what social adjustment consisted of. Seconaly, several writings were read on adjustment inventories, writings in which the author devised concrete tests that would measure the social adjustment of the individual. Although, none of the specific questions suggested in the inventories to juage the social adjustment of the girls were used, the writer aid, however, use the categories of social adjustment sugested by

20. Excluding cases of rape or force 
H. Mi. Bell and used his suggestions on how to attribute weights to each of the categories. Through this method she arrived at some device, however orude, for measuring the social adjustment of each girl that the witer interviewed. Let it be noted here that more work in this area of devising objective measures as to what is good social adjustment for such a group as the one studied here or a similar group is sorely needeả.

In trying to judge the social adjustment of the individual, the concept of adjustment may have at least two meanings. 1. It may be considered in terms of an objective evaluation of conact by another individual.

2. It may be considered in terms of the individual's own evaluation of his behavior and his own feelings about it.

The second approach, was more or less adopted by the writer to judge the girl's social adjustment. This was done not necessarily because it was felt that it was the better one, but because of the practical consideration involved. "An objective evaluation of conduct by another individual" would entail observation for a longer period of time than it was felt could be devoted to each individual study of each girl. Judgements were based mostly on the statements made by the girl as to what her life was like and how she felt about it.

The actual method used in judging the social adjustment of the individual girl was two-fold. First a short resume describing the life of the girls at the time the 
follow-up study was made, was written up on each of the twenty seven girls. This resume included such headings as: home adjustment; social adjustment (relationship to people other than family); emotional adjustment and vocational adjustment. From these resumes subjective judgements as to whether the girl's adjustment was Good, Fair, or Poor were $\operatorname{made}$

These subjective judgements of the writer were compared with the ratings that each girl made on the adjustment test 21

devised. The adjustment test included four categories the same as the ones used in the subjective juagements-Home, Emotional, Social and Vocational Adjustment. Under each of these categories certain subaivisions were included. Each category and its subdivisions were attributed maximum weights on the basis of one hundrea per cent (100\%) for the grand total. Each category did not receive the same maximum weight, but was weighted according to its importance in the total adjustment picture. Emotional and Social Adjustment both received maximum weights of thirty per cent $(30 \%)$ each, while Home dajustment received a maximum weight of twenty two per cent $(22 \%)$ and Vooational Adjustment a maximum weight of eighteen per cent $(18 \%)$. If the Eirl reoelved a total soore of betwe en 100\%-70\% her adjustment was considered cood; if the Eirl received a total score of between $69 \%-40 \%$ her adjustment was considered Fair; if the girl received a total score

21. See Appendix D 22. Comparative ratings for the categories taken from $F$. M. Bell, The Theory and Practive of Personal Counseling, Staniord University Press, 1939 
of $39 \%$ and below her adjustment was considered Poor.

In twenty two of the total twenty seven cases both the results of the subjective and the objective rating were the same--a total of eighty two per cent (82\%) agreement. To make the final judgement of the adjustment of the five cases where there was no agreement, the writer's thinking about the matter ruled. The five cases not in agreement showed no wide discrepancy between the two measures, but occurred where the girl had received a borderline rating.

Table twenty three below shows the adjustment of the group of twenty seven girls according to how they made out in the individual categories of adjustment. The table following, table twenty four, will show the total results of the adjustment of the girls. 
Table 23

Social, Home, Emotional, and Vocational Adjustment Rating's of the Twenty Seven Unmarried Mothers in Relation to Their General Aajustment Rating

\begin{tabular}{|lr|r|r|r|}
\hline & & Good & Fair & Poor \\
Social Adjustment & 27 & 4 & 18 & 5 \\
Total More than $\frac{1}{2}$ credit & 5 & 3 & 2 & 0 \\
Half \& less than $\frac{1}{2}$ credit & 22 & 1 & 16 & 5 \\
\hline Home Ad jus tment & & & & \\
Total & 27 & 4 & 18 & 5 \\
More than $\frac{1}{2}$ credit & 15 & 4 & 11 & 0 \\
Half \& less than $\frac{1}{2}$ credit & 12 & 0 & 7 & 5 \\
\hline Emotional Adjustment & & & & \\
Total & 27 & 4 & 18 & 5 \\
More than $\frac{1}{2}$ credit & 21 & 4 & 15 & 2 \\
Half \& less than $\frac{1}{2}$ credit & 6 & 0 & 3 & 3 \\
\hline Vocational Ad justment & & & & \\
Total & 27 & 4 & 18 & 5 \\
More than $\frac{1}{2}$ credit & 24 & 4 & 17 & 3 \\
Half \& less than $\frac{1}{2}$ credit & 3 & 0 & 1 & 2 \\
\hline
\end{tabular}

Table 24

General Adjustment Ratings of the Twenty Seven Unmarried Mothers

Ad justment

Unmarried Mothers

Good

4

Fair

18

Poor 
The writer felt it might be of value to illustrate from the actual cases what was considered Good, Fair and Poor adjustment in inaividual cases. Below are actual illustrations of Good, Fair, and Poor adjustment with brief introductions of the girl's social history previous to her contact with the Children's Agency.

Illustration E--Illustration of a case where the girl had Received a Good Adjustment Score.

KAREN'S little illegitimate boy, Tommie, was borm when Karen was twenty one years ola. Karen had spent a sood part of her life at a public chila welfare institution. When the girl was eight years old her parents separated and because Karen's mother declared that she was incapable of caring for her, the girl was admitted to the institution as a dependent child. At the institution, Karen was known as a frequent runaway. When Karen was sixteen years old she was released from the institution to go live with her mother. When Karen joined her mother's household, the mother was at the time living with her paramour, her son and his mistress. Shortly afterwarās Karen's father who was at the time old and senile and dubbed "mentally peculiar" came to live with them too.

Karen often expressed aisgust with her mother's and brother's immoral habits and with her father who lived with them and looked on passively at all that was going on.

Although Karen had been released from the institution in which she spent eight years of her life, they nevertheless 
still supervised her and showed interest in her. The institution helped her through three years of High School and then sent her for eighteen months to a business college for secretarial training. Karen apparently became disgusted with the conditions in her home and at the age of twenty left and went to live at a girls' boarding home. While at the boarding home she lost her job and while looking for work she met the father of her child. He was an employee of one of the employment agencies.

It was noted in the Children's Agency record that Karen was suspected of soliciting men before her illegitimate pregnancy. When she became known to the Children's Agen cy she was studied by a psychiatrist. In the psychiatrist's observation of Karen's personality he noted in his record that she showed confusion in her emotional ana intellectual attituae towaras members of her family. She also, he noted, showed a "certain personal inadequacy probably resulting from a long period of aependency in an institution." He concluded that Karen had good intellicence, seemed calm and stable in her nervous make-up and he thought her to be capable of guidance and development.

Karen's attitude towards her illegitimate pregnancy was fairly mature and constructive, the worker felt. She decided to keep her child and her family promised to help her with this decision. When Karen's case was 
first closed by the Children's Agency in January, 1935, Tommie was with his maternal grandmother who cared for him while Karen worked and lived in her brother's home. In July, 1938, when Tommie was about seven years ola, Karen again applied to the Children's Agency for help. She wanted foster home care for her child who had been living with his maternal granamother all this time. She was dissatisfied with the arrangement. Although Karen had married, the previous year, a man not the father of her child, she felt that she could as yet not take Tommie in her home. She was working in order to help her husband who was not making very much at the time. Tommie stayed at the foster home for a little over a year. He was then taken from the foster home into the home of his mother and step-father. Karen's case was last closed in January, 1940. At the time of the follow-up visit, Karen, her husband, and Tommie lived in a fairly nice, fairly respectable neighborhood of working people. They occupied a large, four room apartment which was well furnished, orderly, and cheerful.

It was early Sunday afternoon and Karen, her husband, and Tommie had just returned from church. Tommie left soon afterwards when some friends oalled him out to play. He was an attractive, pleasant and seemingly wellbehaved youngster. Both his mother and his step-father seemed proud of him and told how well he was doing at 
school.

Tommie called his step-father "Dad" and although he was

a little more than five years old when his mother married, he never seemed to question his paternity. Karen seemed worried about this and faced the problem that she must tell him the entire situation sometime. Karen's husband, who was present throughout the interview and took part in it, said he too faced this problem with fear, ano said that he wanted to put off discussing this as lonf as possible. Fe has accepted the youngster as his own and hated taking the matter up with him lest Tommie begin outwardy to feel that there is a difference. Karen and her husband, although married seven years at the time of the follow-up visit, had no other children. Their present neighbors did not know the truth of Tommie's paternity, and Karen poses as a widow who had a child before she married her present husband. In discussing her present life, Karen said she considered herself quite fortunate. Although she and her husband have their differences at times, they are on the whole compatible. He is kind, affectionate and good towaras her as well as her chila.

Until a year ago when she returned to work, she stayed home to care for Tommie and the home. She explained that she had too much nervous energy to stay at home and that Tommie, now quite grown up, did not need her as much as he used to. She was enthusiastic about her 
work, which was a elerical position in one of the war plants. Her work and her work companions gave her a good deal of satisfaction. Fer husband too has a good job ana together they made a comfortable income. Since she is working they do not go out very much. Both are interested in church activities and visit friends and relatives. While the writer was in the home, Karen Eot quite a number of calls from friends who wished her a happy birthday and some invited her to their homes. She talked about the past and the father of her child seemingly without much pain or embarrassment. She said that she accepted what had happened as "something that should not have happened, but since it did should not ruin her life". She said that looking back at it she felt that she had acted as she did becuase she had led a sheltered institutional life for some time and then was suddenly let out without much preparation for living in a "Iree world". She said that she has never regretted her decision to keep Tommie, although it was many times "tough going". She summed it up that her life had turned out very satisfactorily in spite of the poor start. Illustration F--Illustration of a Case Where Girl Received a Fair fidustment Score.

EIIA's mother died when she wa's a child of four. When Ella was eight years old her father remarried and the Eirl was living with her father, step-mother, one half brother and sister at the time she became known 
to the Chilaren's Agenoy.

She was twenty years old when she became illegitimately pregnant. The worker described her as an extremely slight and frail looking firl. She seemed very shy, but had a quiet and sincere manner. Ella's stepmother had accompanied her to the acency and requested meternal home care for the girl. The step-mother seemed affectionate with Ella and claimed that there was no difference in her feelings towards this girl and her own children. She seemed very protectivé of Ella, claiming Ella was too weak to go to work. Flla was staying at home caring for the house and younger children when she first came to the agency. While the relationship between Ella and her step-mother seemed to be good, the relationship between Ella and her father, on the other hand, seemed strained and difficult. The father was a rather heavy drinker, and had, on one occasion, when drunk, thrown Ella out of the house. Both the step-mother and Ella's father were unemployed at the time Ella's case was known to the Children's Agency. The family was partially dependent upón a public agency for financial assistance. Ella was a High School graduate and had had a good record at school. Her step-mother claimed that she had never run around much, was timid and shy, and on the whole had never Eiven them any particular trouble. The father of her child, Ella said, was a boy in the 
neighborhood, a boy about her own age. Ella quite sincerely confided to the worker that she was "crazy about him." She could not explain why she first became sexually intimate with him, but said it became a natural happening between them.

According to the social worker, Ella faced her illegitimate pregnancy rather maturely and realistically. She wanted to keep her child in spite of the fact that her family, especially her father, urged her to give it up from the beginning. He definitely stated that he would not allow her child in his home.

Ella gave birth to her child, a boy, at the maternity home and then relatives took Ella and Dickie into their home. Ella's father and step-mother resented this, and they claimed that Ella would have given her child up if the relatives had not interfered. Flla's case was closed by the Children's Agency in August, 1938.

A follow-up visit was made to Ella in December, 1943, a period of a little more than five years after her record was closed by the Children's Agency. The writer found Ella and her son, Dickie, living at the home of her father and step-mother. The home was in a poor working class neighborhood, but was respectable. The house was neat, orderly, and clean, and comfortably furmished at the time of this visit. Ella and her stepmother were sitting in the kitchen talking while Ella's father was occupiea in another room fixing some bit of the furniture. The home seemeo comfortable and there was a 
cheerful, homey atmosphere pervading it. Ella, a slifht, clean-cut and nice looking girl, greeted the writer and when the purpose of the visit was explained to her, she agreed to help to the best of her ability. Ella told the writer that she had married about a year ago a boy whom she haa known before her illegitimate pregnancy. He was in the Army when she married him. Fo had oome home on a furlough, married her, and returned to camp. She admitted quite frankly that she had married this boy not because she loved him, but for the security he could offer her. She said in explanation of this that since her child was corn, her attitude towards love and marriage had changed. She wanted now mostly security, consideration, and a man that she could depend upon, and she thought that perhaps she had found this in her husband. She further indicated that she was not in love with her husband when she explained that her child calls his step-father by his' first name, and she did not think she would encourage the child to call him "father". She said rather hesitatingly that she might perhaps not have married this man if she did not have an illegitimate child.

As she looked back at the situation, Ella felt as she so aptly put it, that "it is not the mistake committed that counts so much, as what you do and how you behave afterwarăs". She did not regret her decision to keep her child with her. She claimed that the responsibility of 
the child gave her the courage to gain financial independence for herself. She was working, at the time of the visit, as a clerical worker at one of the war plants and was holding quite a respensible position. She liked her work and her companions at work. As for activity outside of work and home, it consisted of very little. She had exceptionally few friends, rarely went out after work and admitted that she was still timid and shy with people. Illustration G--Illustration of a Case where the Girl Received a Poor Ldjustment Score.

DOROFHY became illegitimately pregnant when she was fifteen years old. The father of her child was a boy of nineteen. They had been friends for over two years. The girl had visited his home and was well acquainted with his family.

Dorothy was an unusually pretty girl, but was quite immature even for her fifteen years. Fer mother claimed that she was always a good girl and never caused them any trouble. She led an exceptionally secluded life, and except for the father of her child had no young companions who visited her. Dorothy's home life, judging by the description in the record, was not a happy one. Her father drank, and had frequent fits of melancholia. The mother was said to be a nervous, high strung, rather narrow-mindea and ignorant 
woman. Further, the worker states that Dorothy's mother thad probably not brought up her children in a way to encourage their own initiative, self-expression or taught them to take responsibility for themselves". Dorothy expressed little feeling about her situation. She seemed utterly dependent on her mother who dominated the situation. The mother's first reaction to the knowledge that Dorothy was illegitimately pregnant, was one of extreme emotional distress. She fainted when she first heard the diagnosis. She tended to have ambivalent feelings towarảs Dorothy, but sympathy for her daughter seemed to predominate. The father, on the other hand, seemed definitely to reject the girl and physically abused her when she was pregnant. The mother decided for Dorothy that she would take the child into her home and rear it as her own. During contact with the Children's Agency the mother became dissatisfied with the agency and felt that it did not work fast enough. She took matters into her ovm hands, went to Police Court and with the help of the court secured a marriage between Dorothy and the father of her child. However, he rejected the girl very soon afterwards. At the time, the agency closed Dorothy's case, Dorothy and her child were in the parents' home. Her husband, who had never lived with her, was in his 
home showing no interest in either Dorothy or their child. After almost a lapse of four and a half years, Dorothy and her child were found to be still living with the girl's parents. She was not working anō was totally dependent upon her parents, both hard working people, for her support. She was found to have grown into a rather unusually pretty Eirl, but also a remarkably ineffective person.

When the writer interviewed the girl, her mother could hardly leave her alone for a moment. She kept interrupting Dorothy when the girl tried to express herself. Her talk was confused and she gave the impression of an extremely disturbed individual. She talked about Dorothy as if the girl was an invalid, and was not like other young firls. "Dorothy sits home all the time, mopes around and has the blues."

Dorothy, although she had married the father of her child, had never lived with him. Two years ago they were finally divorced. Dorothy still seemed to feel fully the sting of his rejection, and her mother did not seem to let her forget the episode of her illegitimate pregnancy and her unfortunate marriage. She dwelt on the most painful aspects of the situation right in front of the Eirl. Dorothy, when given a chance by her mother, said that she still looks back at the situation with extreme pain and bitterness. It makes her nervous just to think 
about it, she said.

Her feelines towards her child seem to be ambivalent. He is raised as her brother and not as her child, al though Dorothy's parents have not legally adopted him. Dorothy also made vague and nebulous complaints about physical ills. She had been to the psychiatric clinic of the public hospital, and the writer discussed her situation with the psychiatric social worker who knew Dorothy for some time after the girl terminated her contact with the Children's Agency. This worker felt from her work with Dorothy that she was an extremely insecure individual. Ier relationship with people was very poor, and she seemed incapable of establishing a normal, wholesome relationship with anyone, even with the aoctors at the hospital. She did not follow-through the psychiatric treatment planned for her.

\section{Table 25}

Adjustment of the Twenty Seven Unmarried Mothers At the Time of the Follow-Up Study According to the Whereabouts of Their Children and the Retention of custody

Whereabouts of the chila

\section{Total}

Child with mother

Child without mother

(mother has custody)

Released custody
Total Good Fair Poor

$\begin{array}{llll}27 & 4 & 18 & 5\end{array}$

$\begin{array}{llll}16 & 3 & 10 & 3\end{array}$

$\begin{array}{llll}6 & 0 & 5 & 1\end{array}$

$5 \quad 1 \quad 3 \quad 1$ 
Table 26

Adjustment of the Twenty Seven Unmarried Mothers at the Time of the Follow-Up study according to the Attitudes of the Family

Attitude of the Girl's Families Unmarried Mothers
Total Good Fair Poor

Total

27

4

185

Ac cept ing

19

4

114

Re jecting:

8

0

71

Table 27

Adjustment of the Twenty Seven Unmerried Mothers at the Time of the Follow-Up Study According to Community knowledge of the True Paternity of Their Illegitimate children

Community Knowledge

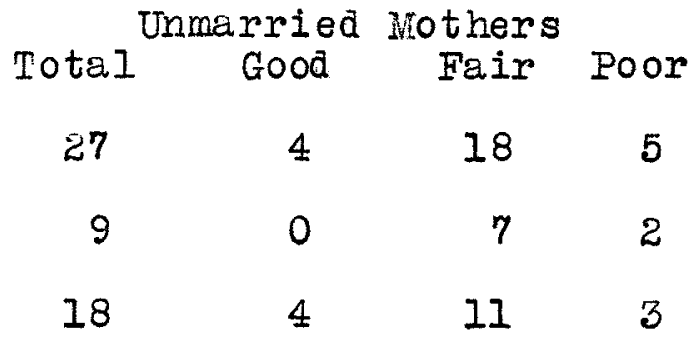

From the data on table twenty seven we find that all of the four girls who managed to make good ratings for adjustment had succeeded in keeping from their present community the truth of what had happened to them. Three of these girls had their children with them, but they were married and that apparently gave their chilaren a legitimate status in the community. The fourth girl who had made a good rating on the adjustment test, was not married, but had given up her child when it was very young, and the community apparently did not have a chance to acquaint itself with the facts. Ileny of the girls had moved out of the old neighborhoods, in order to 
avoid discussion of the experience.

Table 28

Adjustment of the Twenty Seven Unmarried Iothers at the Time of the Follow-Up Study according to Their viarital Status

Narital Status

Unmarried Hothers

potal Good Fair Poor

Total

$\begin{array}{llll}27 & 4 & 18 & 5\end{array}$

Married

17

3

12

2

Divorced

2

0

1

1

Se para.ted

1

0

1

0

Single

7

1

4

2

\section{Table 29}

Adjustment of the Twenty Seven Unmarried Mothers at the Time of the Follow-Up Study According to Marriage to the Fathers of Their children or to other Men

Has Been or Is Married to:

Unmarried Mothers Total Good Fair Poor

Total 27

4

18

5

To the father of the child

5

0

4

1

To another man

15

3

10

2

Single

7

1

4

2

It should be noted from the data in Table twenty nine that of the four girls who made good ratings on the adjustment test, the three that were married were not married to the fathers of their children.

Nineteen of the total of the twenty girls that had been or were still married at the time of the follow-up study claimed that their husbands knew the truth of the paternity of their 
children. The remaining, one girl, who had been married three years at the time of the follow-up interview and whose husband had been in the Army for fourteen months, claimed that she had never told her husband the truth surroundine the conception of her chila. She told him that the child was a child by a previous marriage. This illegitimate child was living with the firl and her husband before he was inacted into the Armed Forces. She admitted that she was very uncomfortable over the situation and was in constant fear lest he find out the truth. Nevertheless she did not have the courage to tell him. She scored a Fair Rating on the Adjustment pest. 
CONCLUSIONS 


\section{CHAPTHR V}

\section{CONCIUSIONS}

Concluding from the study of these thirty eight cases, conclusions which admittedly can carry no great weight because of the limited number of cases here studied, we note that the opportunities of the unmarried mother to marry would be as numerous as in any other group. A total of twenty eight out of the thirty eight girls were found to have married at the time of the follow-up study. It should be noted that the resulting percentage married of the girls in this study was larger than other studies made that had as their purpose to measure the same thing. Although, it was impossible to find accurate statistics as to the general marital rate in the community during the same period, the writer strongly suspects that the war situation had a good deal to do with this higher percentage of marriage in the group studied. Eight girls were found to have married the fathers of their children. The remaining twenty married other men.

Some of these girls who had married were found to be either divorced or separated from their husbands and an attempt was made to compare the marital status of the girl who had married the father of her child and the girl who 
had married a man other than the father of her child. It was found that four of the girls who had married the fathers of their children were no longer living with them--a total of fifty per cent $(50 \%)$. On the other hand only four girls--a total of twenty per cent (20\%)--of the twenty girls who had married men other than the fathers of their children were no longer living with their husbands. The numbers were admitteaIy too small for the writer to make any definite conclusions. Also, it must be recognized that as noted previously, an element of force entered into some of the marriages between the unmarried mother and the father of her child which might very well have proved detrimental to a satisfyine relationship between husband and wife. However, it did seem from the findings that the girl who married a man other than the father of her child had the better chance to establish a more stable hime life for herself.

One of the controls for the selection of the cases was that these firls had retained the custody of their children at the time the a gency closed its record. As a result the writer started out with all of the girls having the legal custody of their children. Of the thirty eight sirls, at the time the follow-up stuay was made, ten girls found it necessary or expedient to part with the custody of their children. Only three of the girls bitterly regretted this occurrence at the time follow-up information was obtained for them. The remainine seven girls looked back upon this step as the only thing they could have done under the 
circumstances. Although twenty eight girls still retained the legal custody of their children only twenty of these girls were with their children. The remaining eight children were living in relatives' and foster homes away from the ir mothers.

In only three cases was peternity established legally for the illegitimate child. In seven cases the children were legitimitized through the marriage of the parents.

In seventeen cases where the girls married a man other than the father of her child the girl rotained the legal custody of her child. In none of these seventeen cases did the step-father adopt the illegitimate child of his wife. Twelve of these children were living in the home of the mother and step-father.

Five out of the total thirty eight girls for whom information at the time of the follow-up study could be obtained, had again become illegitimately pregnant. Four of these actually giving birth to another illegitimate child. The remaining one girl performed a self-induced abortion.

As was anticipated due to the war prosperity which prevailed in the community at the time the follow-up was made, the economic status of the thirty eight girls had greatly improved. At the time The Children's Agency had contact with these sirls, thirty six of these girls rated as

23. Although eight of the girls married the fathers of their children, one sirl married the father after she hed already given up her child for adoption which recessarily prevented its legitinization. 
totally or partially dependent or were in a marginal economic group; at the time of follow-up only twelve girls were to be found in these categories.

A much wider range in vocations was found for these girls at the time of the follow-up study as compared with their vocations at the time they were known to the agency. The writer is of the opinion that the tremendous economic opportunities which prevailed in the community in November and December of 1943 affected our results. It is interesting to note, that no longer were the majority of the girls found in what may be called the "traditional employment of the unmarried mother"--the domestic servant and the waitress. At the time of closine, twenty two of the girls out of the twenty nine whose vocations were known were working as domestic servants or waitresses; at the follow-up only four were known to be domestics or waitresses.

As regards the ratings of the general adjustment of the twenty seven firls that the writer interviewed personally it was found that twenty two eirls could be considered as well or fairly well adjusted, with the remaining five girls receivine poor ratings as to general adjustment.

Again, it was found, although the findings are far from conclusive that marriage to the father was not a very favorable factor towards Eood general adjustment. Out of the four girls who rated Good on the adjustment test, the three that had married and were still married had not married the fathers 
of their children. The fourth girl was single.

It is interesting to note, that the poorest ratings that were made were in the area of social adjustment or relationships with people. only five of the twenty seven eirls received more than half credit in this category. one girl who rated a Good general adjustment and rated high in the other three areas of adjustment--Home, Emotional, and Vocational-received a rating of less than half credit in the area of social adjustment. Whether this is because, as some writers in this field maintain, that inability to maintain good relationships with people is one of the primary causes for illegitimate pregnanoy or because of the fact that the girls felt timid and insecure with people because they had had an illegitimate child is open for further speculation. The writer would have liked to have answered this question at least for this Eroup, but it was impossible because of lack of information on the social adjustment for the eirl before her illegitimate pregnancy. It can only be guessed that the poor social backErounds of these girls, that we have found true for most, would perhaps have made their relationship to other people less wholesome and less secure than what is generally accepted as normal even before their illegitimate pregnancy. 
GIRL'S EISTORY DURING CESE WORK TREATYENT AT CHIIDREA 'S AGENCY

I. Iiving arrangements when she first came to agency

1. stayed at home (place where she previously lived)

2. parents or relatives took her in

II. Age when she became pregnant

III. At work or in school at time when she became pregnant

IV. Age of alleged father

V. Alleged father's marital status

VI. Attitudes:

1. of the geirl

a. towards her situation and pregnancy

b. towards alleged father

c. towards member of her family

a. towards her child

2. of the family

a. towards the girl

b. towards her situation

c. towards the disposition of the child

VII. Part alleged father played in situation

a. did he recognize child as his (informally)

b. did he cooperate with agency

c. did he sympathize with eirl and try to help her

a. unidentified 
VIII. Girl's relationship with alleged father before pregnancy

1. rape or force

2. casual relationship

3. love or relationship of long standing

IX. At time of closing

I. where child

2. where girl

X. Was paternity estaklished legally

II. Is alleged father supporting or contributing to the support of the child

XII. Narital status of mother at closing 
GIRL'S SOCIAI HISTORY AT THE TIEE SHE CAME TO THE ATTENTION

OF CIIIDREN' $S$ AGENCY

I. Name

II. Adaress

III. Date of birth

IV. Living arrangements

1. lived with one or both parents

2. lived with relatives

3. Iived with friends

4. alone

5. in an institution

V. At what age aid she leave home? Reasons

VI. Marital relations of parents

VII. Girl's age when mother or father died or separated

VIII. Relationship of eirl and her parents

IX. At what age did she first begin to work

X. What kind of jobs had? Vocation at present?
1. how many
3. conditions of work
2. pay
4. type of work

XI. Education
1. grade attained
3. scholarship
2. age left school
4. conàuet 
XII. Intelligence

I. Q. rating or remarks in record as to mental capacity

XIII. Relation with family

1. number of brothers and sisters

2. in close contact with them? (before illegitimate pregnancy)

3. any others in family illegitimately preenant or delinquent known of

XIV. Recreational activities

1. friends and companions

2. activities indulged in

3. habits

4. relationship with men

XV. Physical environment of home and neighborhood

XVI. Economic status of parents or girl

XVII. Personality

1. health

2. physical appearance

3. maturity

XVIII. Was there any indication that girl was a problem before XIX. Any other previously known pregnancies XX. Remarks: 


\section{APFEIDIX C}

\section{FOLIOW-UP STUDY}

\section{Name}

II. Address--any indication of a good deal of mobility?

III. Age of mother

IV. Age of child

V. Narital status of mother

1. married, divorced, or separated

2. is she married to child's father

3. did she meet her husband before or after the birth of the child

4. how long after she became pregnant did she marry

VI. Marital relations

1. does he know her story

2. how does she regard her marriage

VII. Any other children in the home

VIII. Attitude of step-father or father towaras child

IX. Status of child

1. name

2. adopted by step-father

X. Whereabouts of child

XI. If not married to child's father

1. relationship of father to the chila

2. is he supporting child in whole or in part 
XII. Attitudes

I. of the mother:

a. towaras situation as she looks back at it

b. towaras the child

2. of the family:

a. acceptance of mother and child

b. rejection of mother and child

3. of community:

a. does it know the truth of the child's paternity

b. any discernable attitudes of condemnation

c. mother's status in eyes of community

XIII. Employment of mother or her economic status now
1. jobs
3. clues of instability
2. wages
4. description of living quarters

XIV. Recreational outlets and habits now

XV. Remarks:

1. is there any acceptable social adjustment

2. has experience proved constructive or destructive 


\section{ADJUSTMENT TEST}

MEXINUN WEIGHTS

I. HONE ADJUSTUENT

$\begin{array}{cc}\text { Total } & 22 \% \\ \text { neighborhood } & 2 \\ \text { Physical appearance of home } & 3 \\ \text { married--marital relations } & 8 \\ \text { single--relations with family } & \\ \text { married--relations bet. man and child } & 5 \\ \text { single-- relations bet. child and family } & 4\end{array}$

II. SOCIAT ADJUSTHENT

$\begin{array}{lc}\text { Total } & 30 \% \\ \text { attitudes towards people } & 8 \\ \text { recreation } & 4 \\ \text { friends } & 6 \\ \text { how she feels people take to her } & 5 \\ \text { (discriminatory or not) } & \\ \text { explanation to community } & 7 \\ \text { (feels comfortable about or not) } & \end{array}$

III. EMOTIONAT ADJUSTMENT

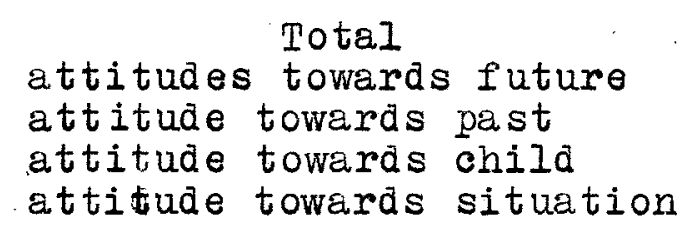

IV. VOCATIONAI ADJUSTMENT

Working

Total

$18 \%$

interest in work pay

or stability

compatible with ability or

Housewife opportunity

GENERAI TOTHES

adequacy of money received from hus.

GOOD ADJUSTILENT

FAIR ADJUSTWANT

$$
\begin{array}{r}
100 \%-70 \% \\
69 \%-40 \% \\
39 \%-00 \%
\end{array}
$$

POOR ADJUSTMETT 


\section{BIBIIOGRAPEY}

1. Alexander, William W., "Interstate Ifigration and Industrial Opportunity", National Conference of Social Work (1941), p. $134-144$

2. Bell, Fugh H., The Theory and Practice of Personal Counseling, Stanford University Press, (1939)

5. Betts, Géorge H., Foundations of Character and Personality, Bobbs-iferrill Co., (1937) New York

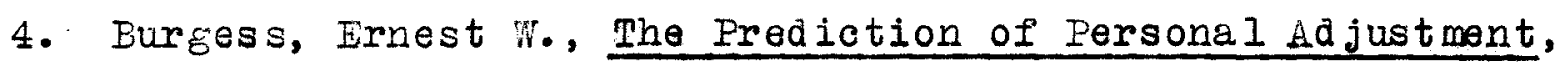
Social Soience Research Council, New York, (1941)

5. Burgess, Ernest W., and Cottrell, Leonara S., Predicting Success or Failure in Marriage, Prentice Hall, Inc., (1939) New York

6. Clothier, Florence, "Problems of Illegitimacy as They Concern the forker in the Field of Adoption", Mental. Hygiene, oct., (I94I) p. 576-590

7. Cohn, Anne, "Survey of Services Given to Fifty Unmarried Miothers by the Jewish Board of Guardians", Smith College Studies in Social Work, Volume 9, (1930)

8. Dexter, Robert C., Social Adjustment, A. A. Knopf, (1927) New York

9. Freeman, Ellis, Social Psychology, Henry Holt and Co., New York, (1936)

10. Groves, Ernest R., Personality anö Social Adjustment, Longmanns, Green anả Co., (1924) New York 
11. Guibord, Alberta and Parker, Ida, What Eecomes of the Unmarried Nother, Research Bureau of Social Case Work, Boston, (1922)

12. Hosmer, Jane, "A Wethod of Predicting the Probable Disposition of Their Children by Unmarried Mothers", Smith College Studies in Social Work, Volume 10, (1939)

15. Kammerer, Perey G., The Unmarried wother, Iittle, Brown and Co., Boston, (1920)

14. Kentworthy, Marion I., The Mental Hygiene Aspects of Illegitimacy, The National Committee for Mental Hygiene, (1921)

15. Kutak, Robert, and Greenwood, Ernest, The Impact of War Upon Louisville Social Agencies, Council of Social Agencies, Louisville, Ky., (1943)

16. Locke, F. H., "Family Behavior in Wartime", Sociology and Social Research, March-April, (1943) Volume 27, No.4

17. Maciver, R. H., The Contribution of Sociology to Social Work, Columbia University Press, (1931) New York

18. Wattingly, Mabel H., The Unmarried hother and Her Child,

- Nestern Reserve University, (1928)

19. Norlock, Niaud, "Establishment of Paternity", National Conference of Social Work, (1940) P. 363-376

20. Noyes, Arthur P., hodern Clinical Psychiatry, W. Saunders Co., Philadelphia, (1940)

21. Plant, James S., Personality and the Cultural Pattern, The Comnonweal th Fund, (1937) New York 
22. Rome, Ruth, " ${ }_{A}$ Stuay of Some Factors Entering Into the Unmarried Mother's Decision Regarding the Disposition Of Her Child", Smith College Studies of Social Work, Volume 10, (1940)

23. Smith, Harriet, "A Descriptive Study of Unmarried Mothers in Relation to the Plans They fake for Their Babies", Smith College Studies of Social Work, Volume 10, (1939) 